\title{
Xylitol production by Debaryomyces hansenii and Candida guilliermondii from rapeseed straw hemicellulosic hydrolysate
}

López-Linares, Juan Carlos; Romero, Inmaculada; Cara, Cristobal; Castro, Eulogio; Mussatto, Solange I.

Published in:

Bioresource Technology

Link to article, DOI:

10.1016/j.biortech.2017.09.139

Publication date:

2018

Document Version

Peer reviewed version

Link back to DTU Orbit

Citation (APA):

López-Linares, J. C., Romero, I., Cara, C., Castro, E., \& Mussatto, S. I. (2018). Xylitol production by Debaryomyces hansenii and Candida guilliermondii from rapeseed straw hemicellulosic hydrolysate. Bioresource Technology, 247, 736-743. https://doi.org/10.1016/j.biortech.2017.09.139

\section{General rights}

Copyright and moral rights for the publications made accessible in the public portal are retained by the authors and/or other copyright owners and it is a condition of accessing publications that users recognise and abide by the legal requirements associated with these rights.

- Users may download and print one copy of any publication from the public portal for the purpose of private study or research.

- You may not further distribute the material or use it for any profit-making activity or commercial gain

- You may freely distribute the URL identifying the publication in the public portal 


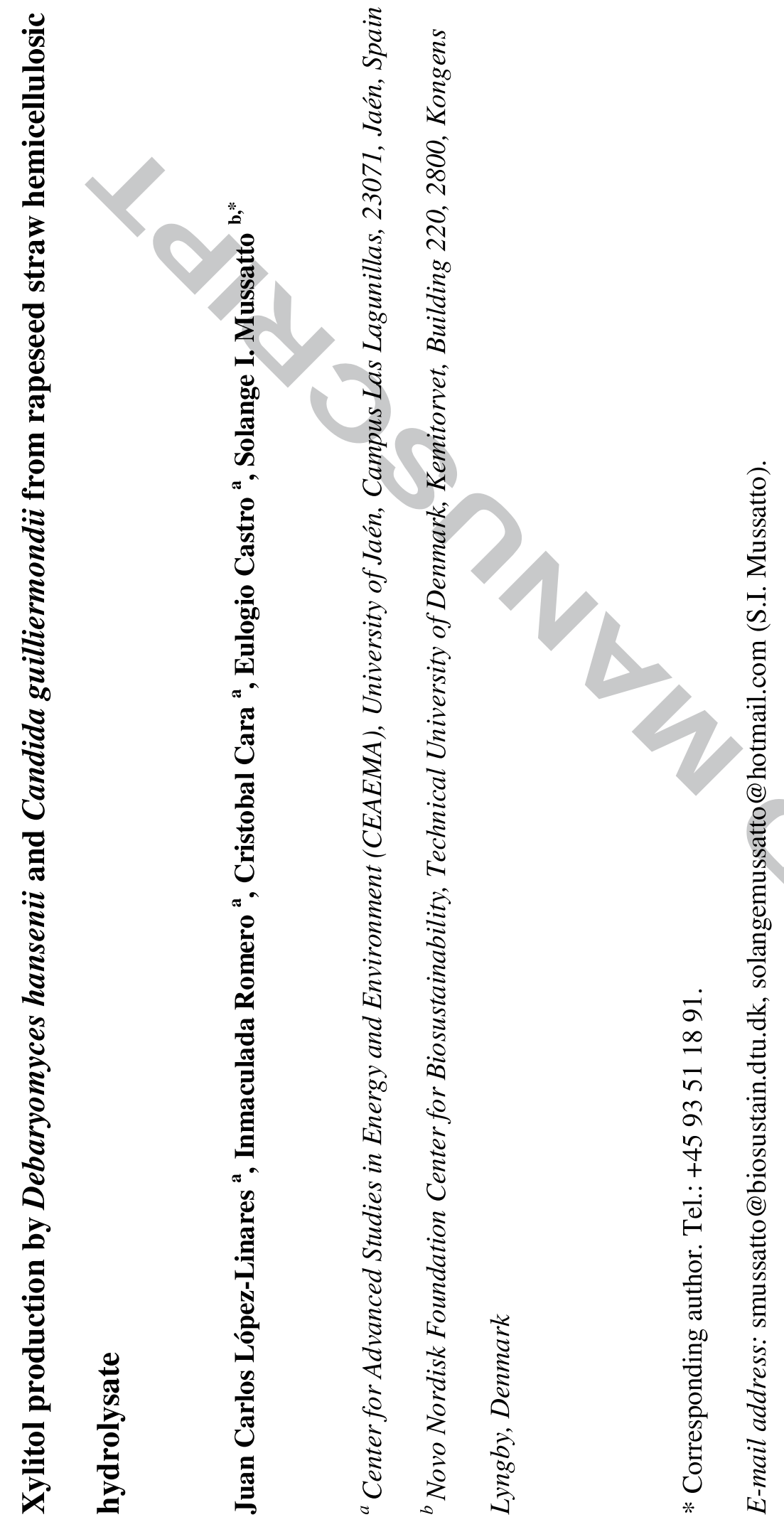



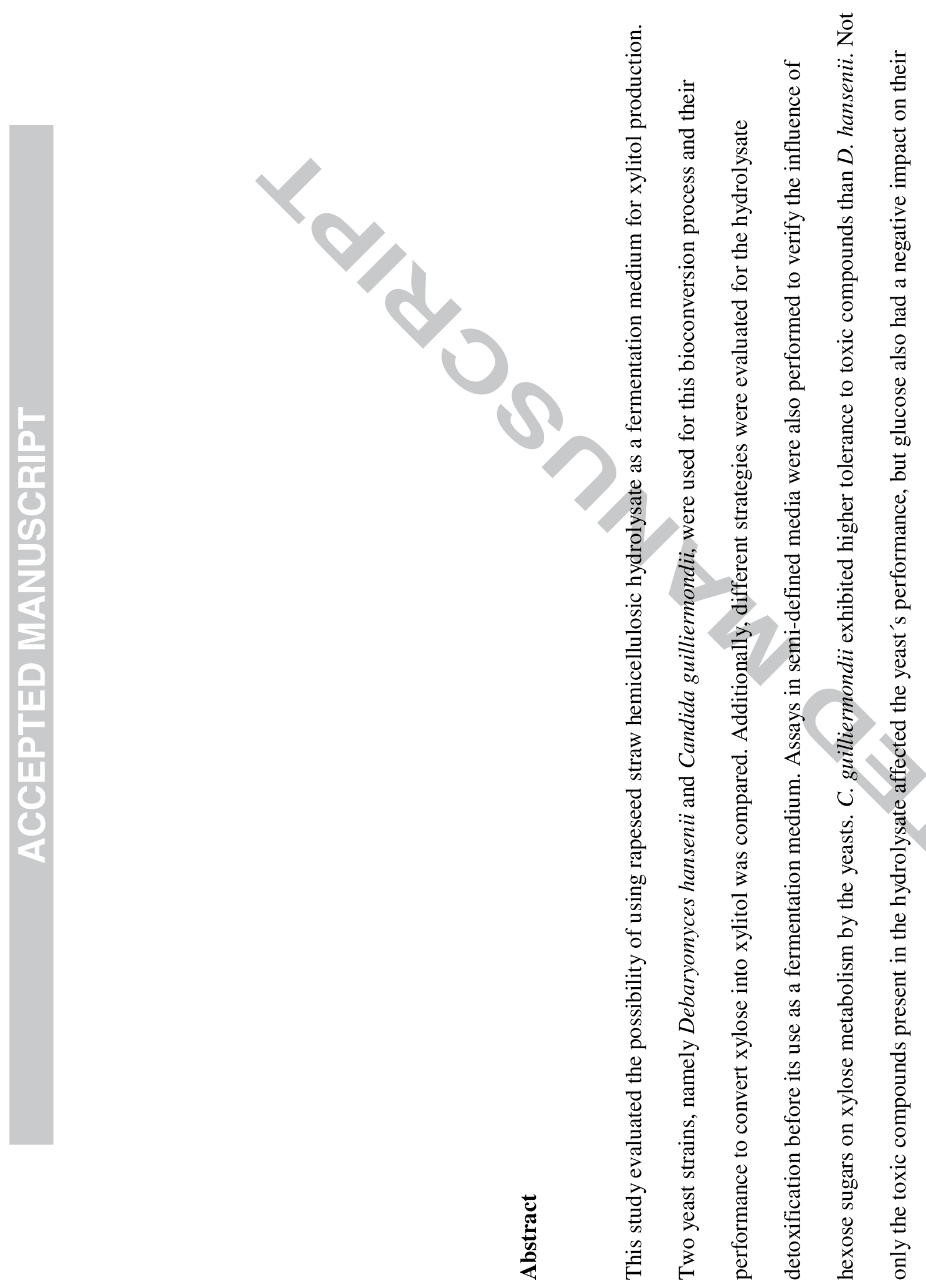

N 


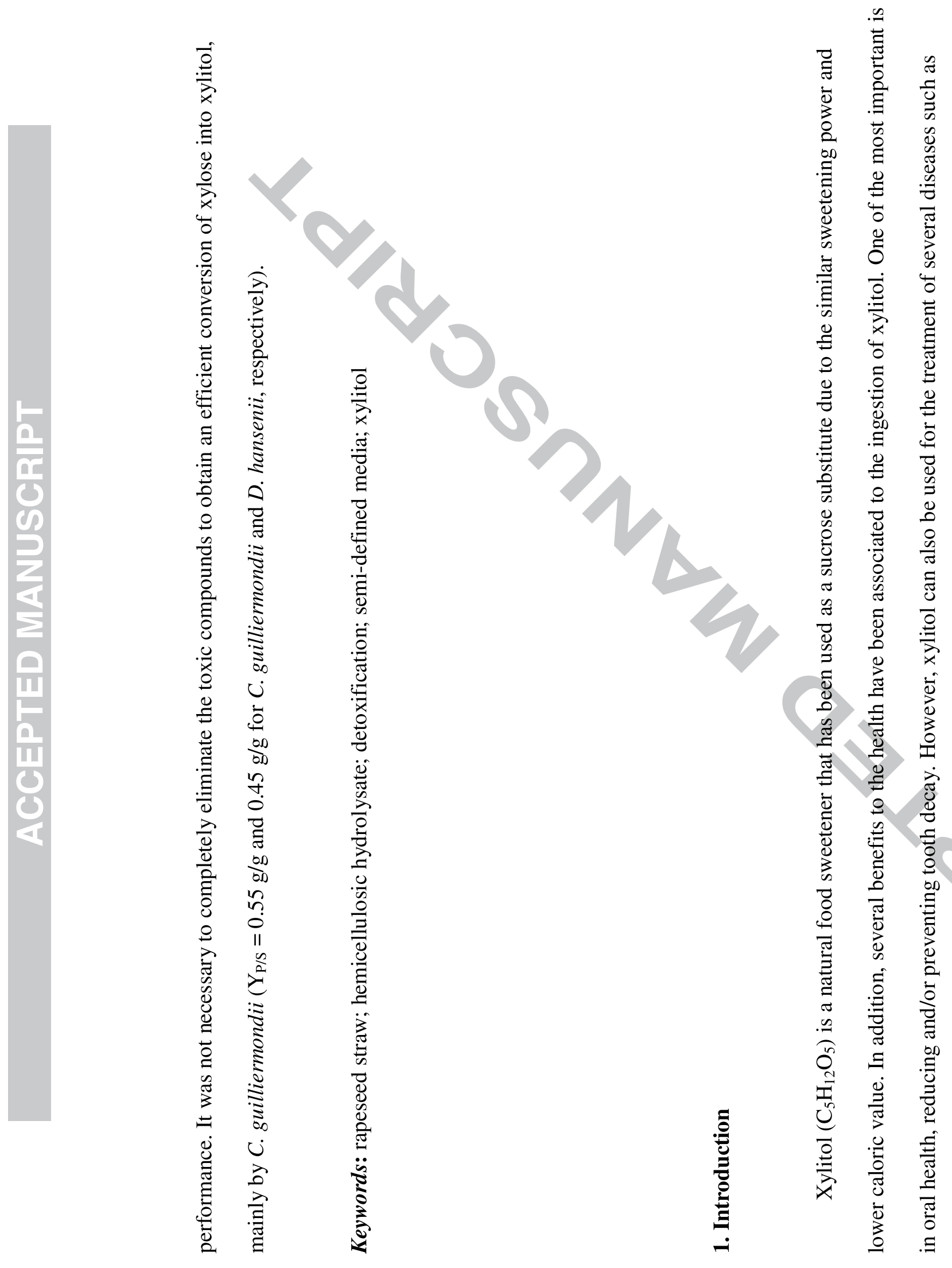




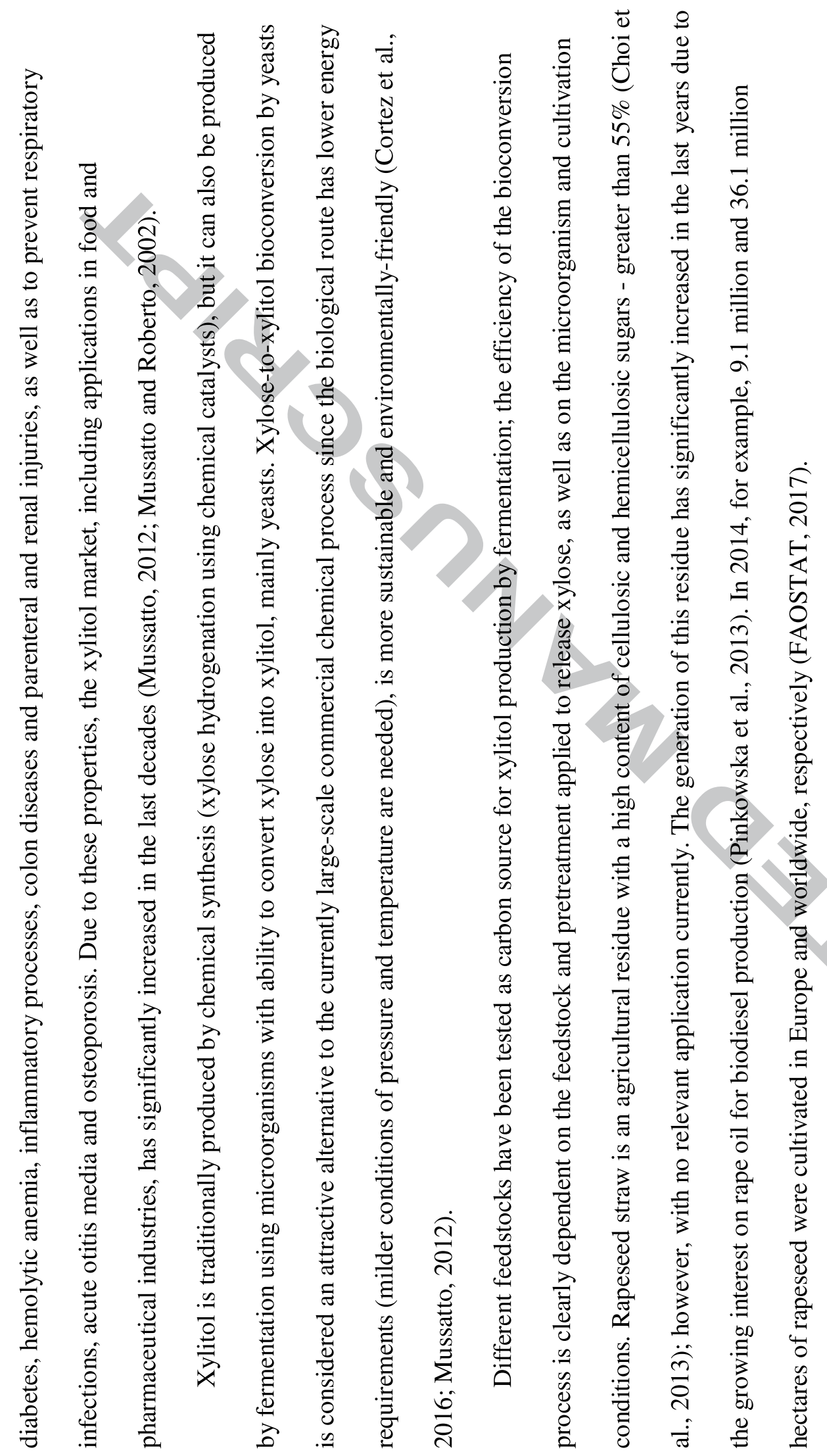




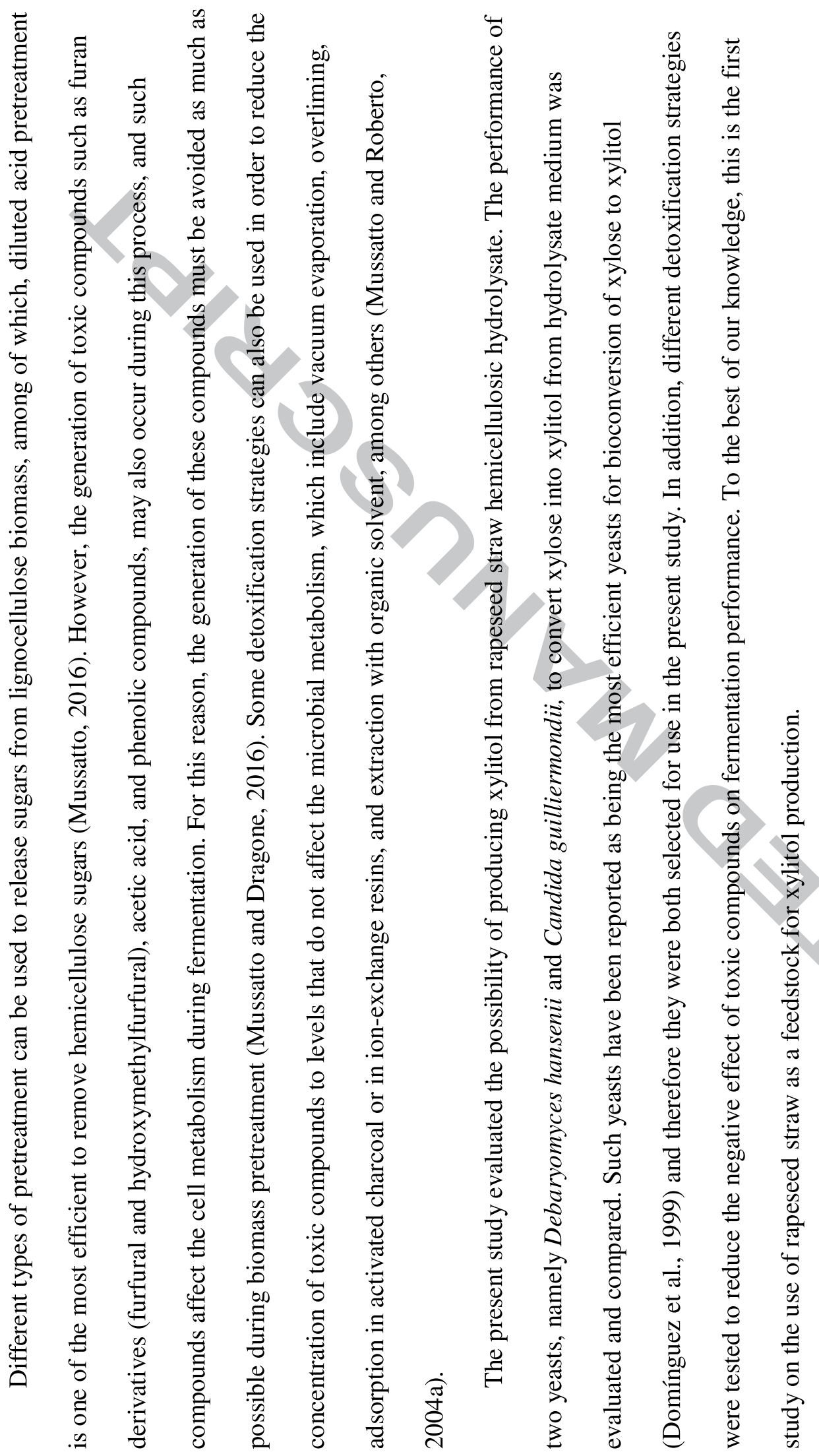




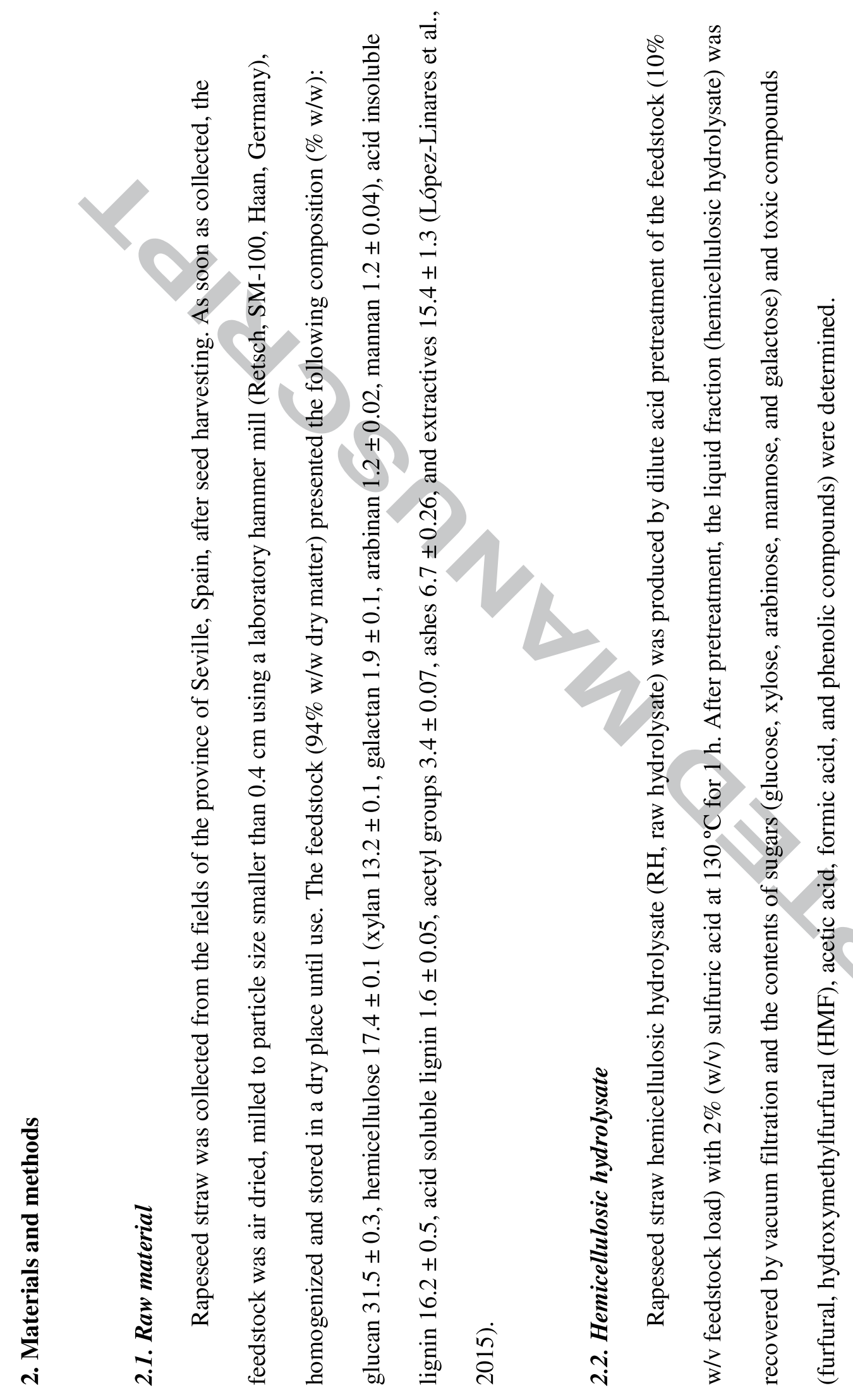




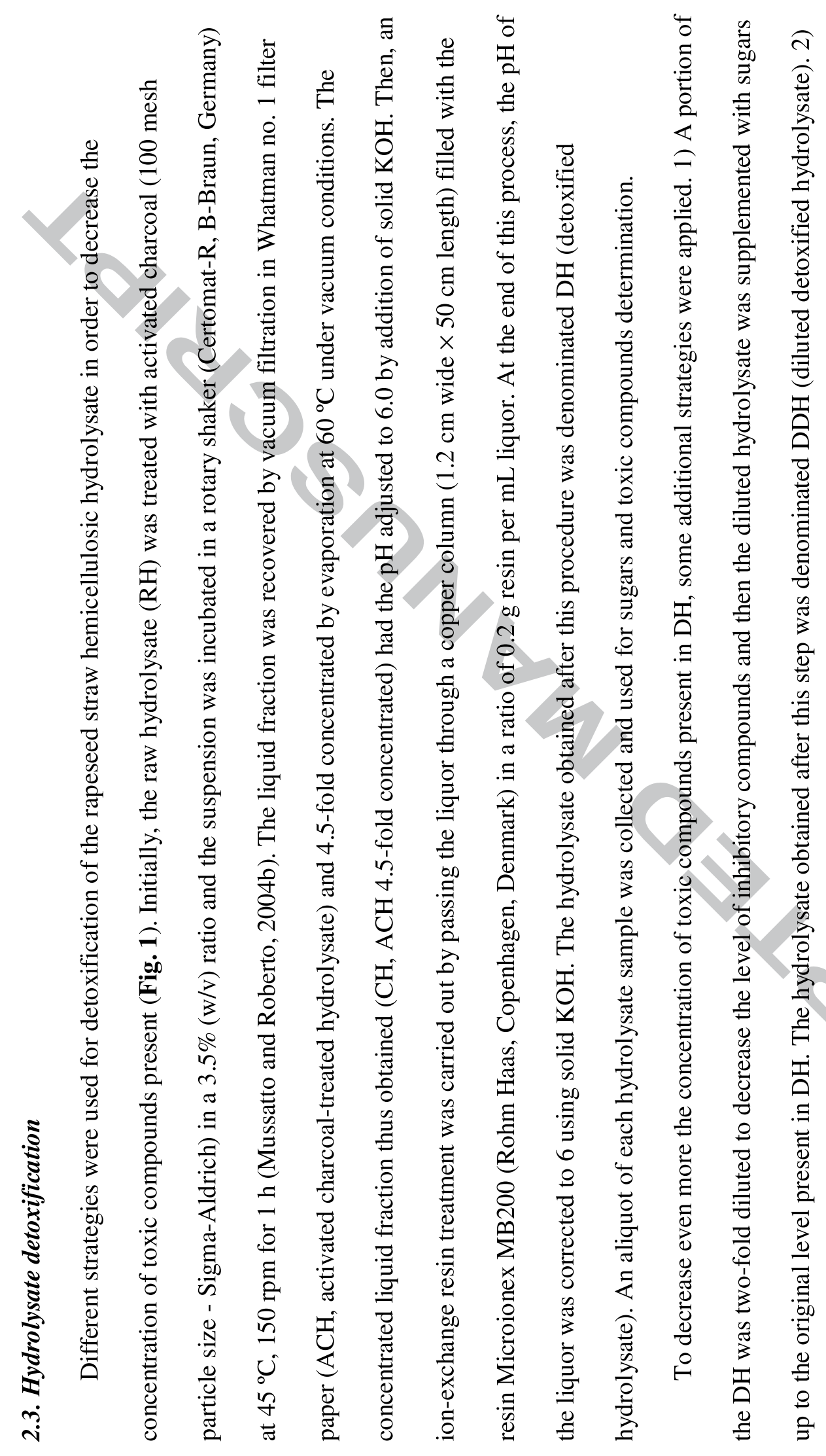




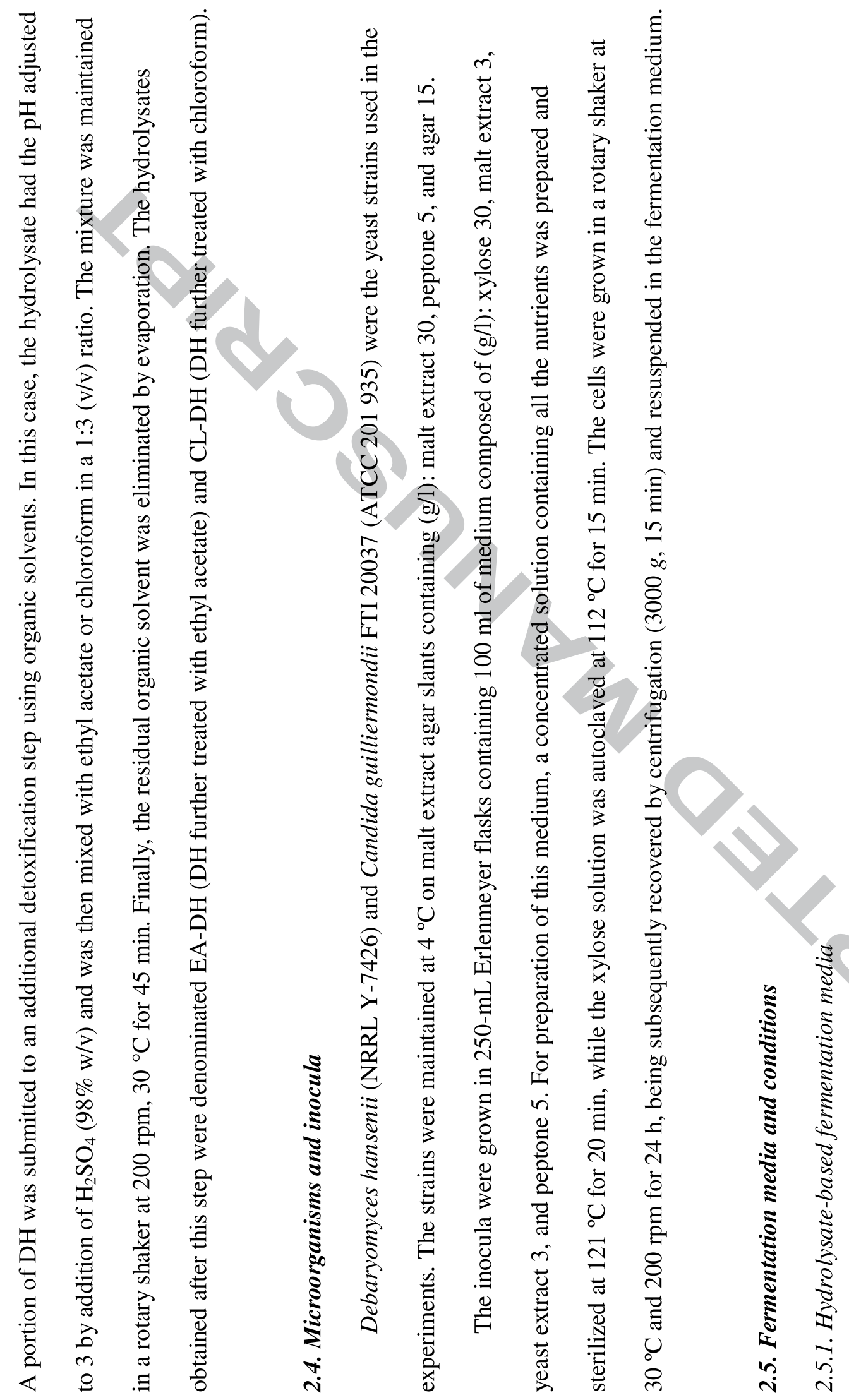




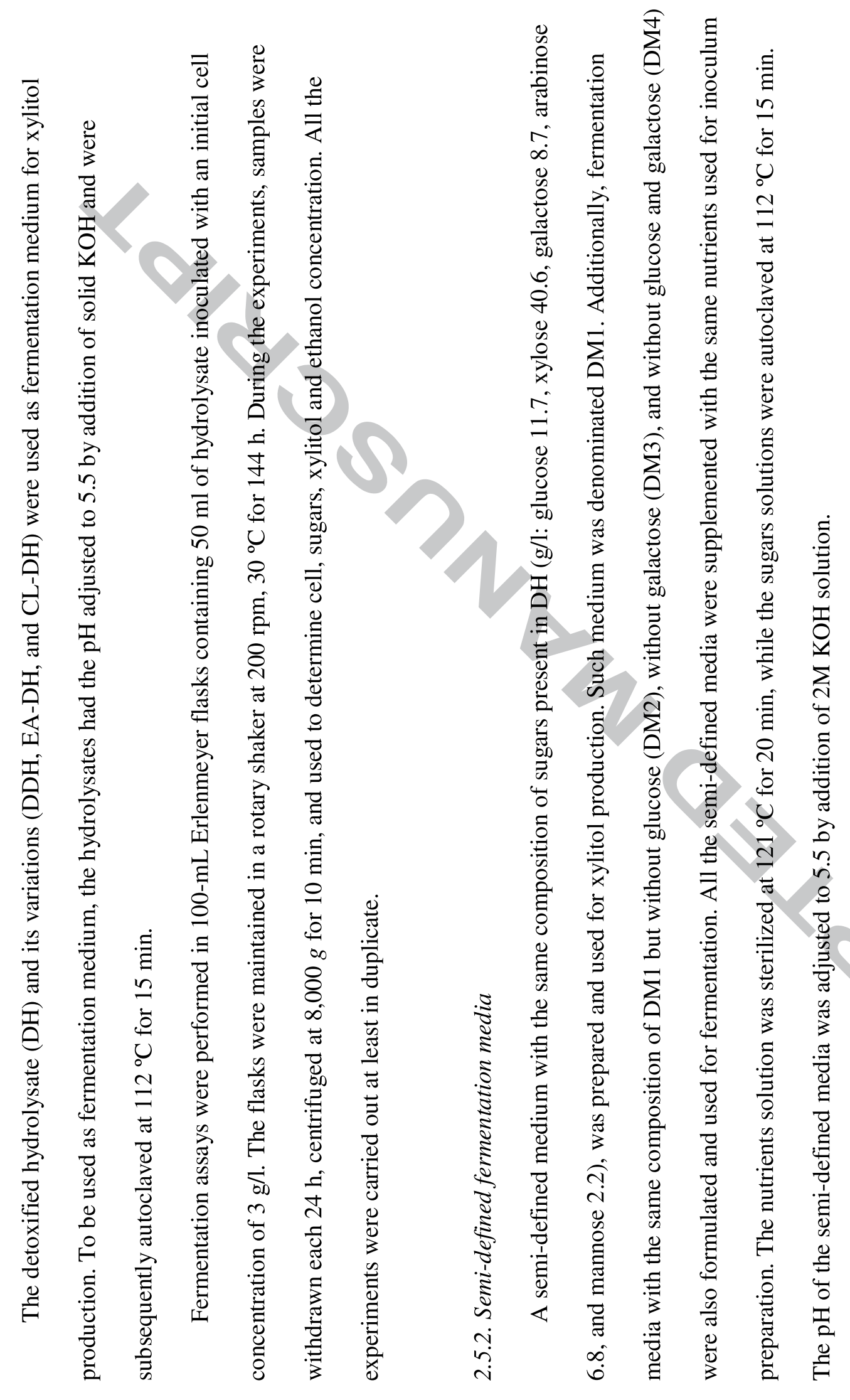

$a$ 


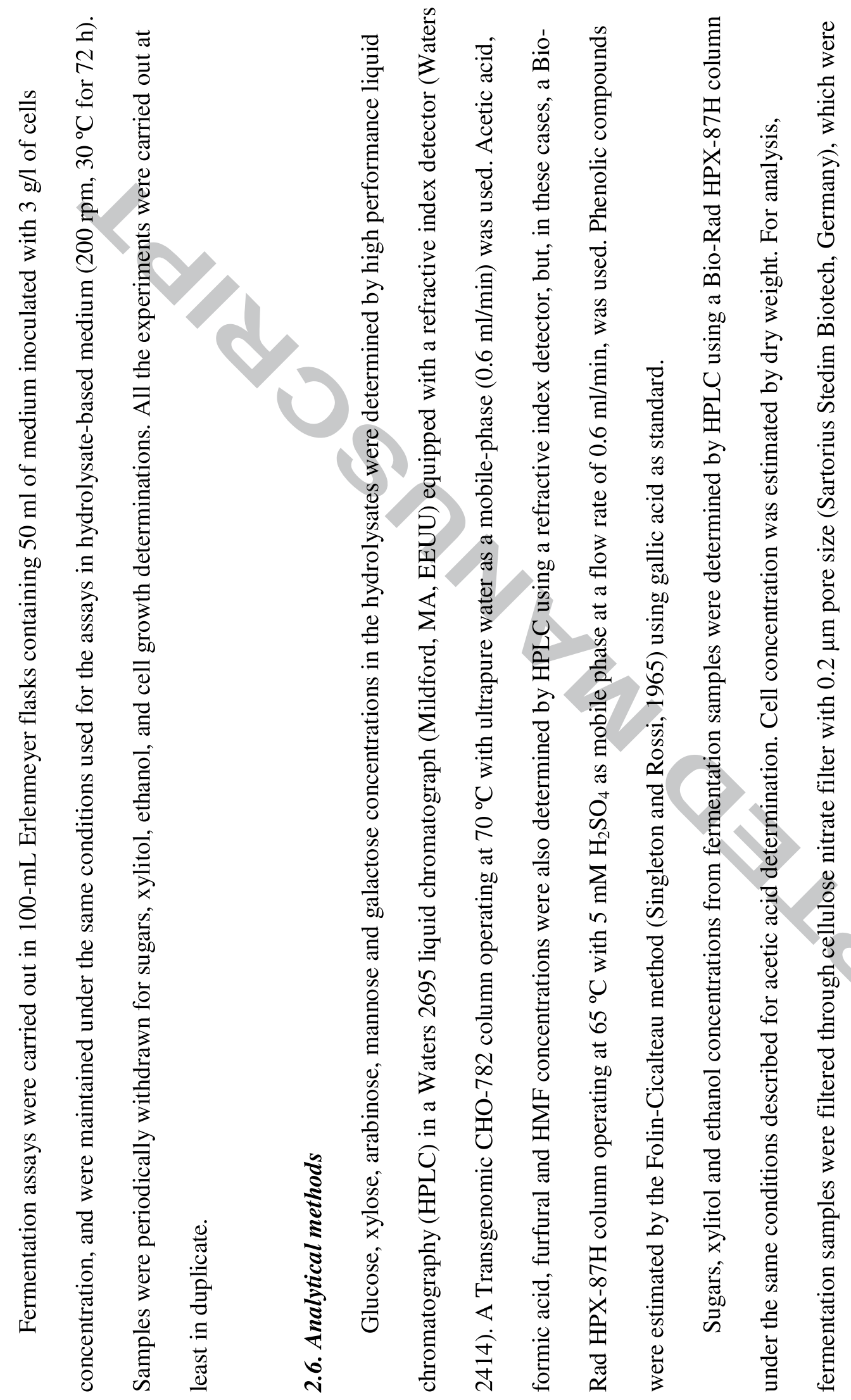




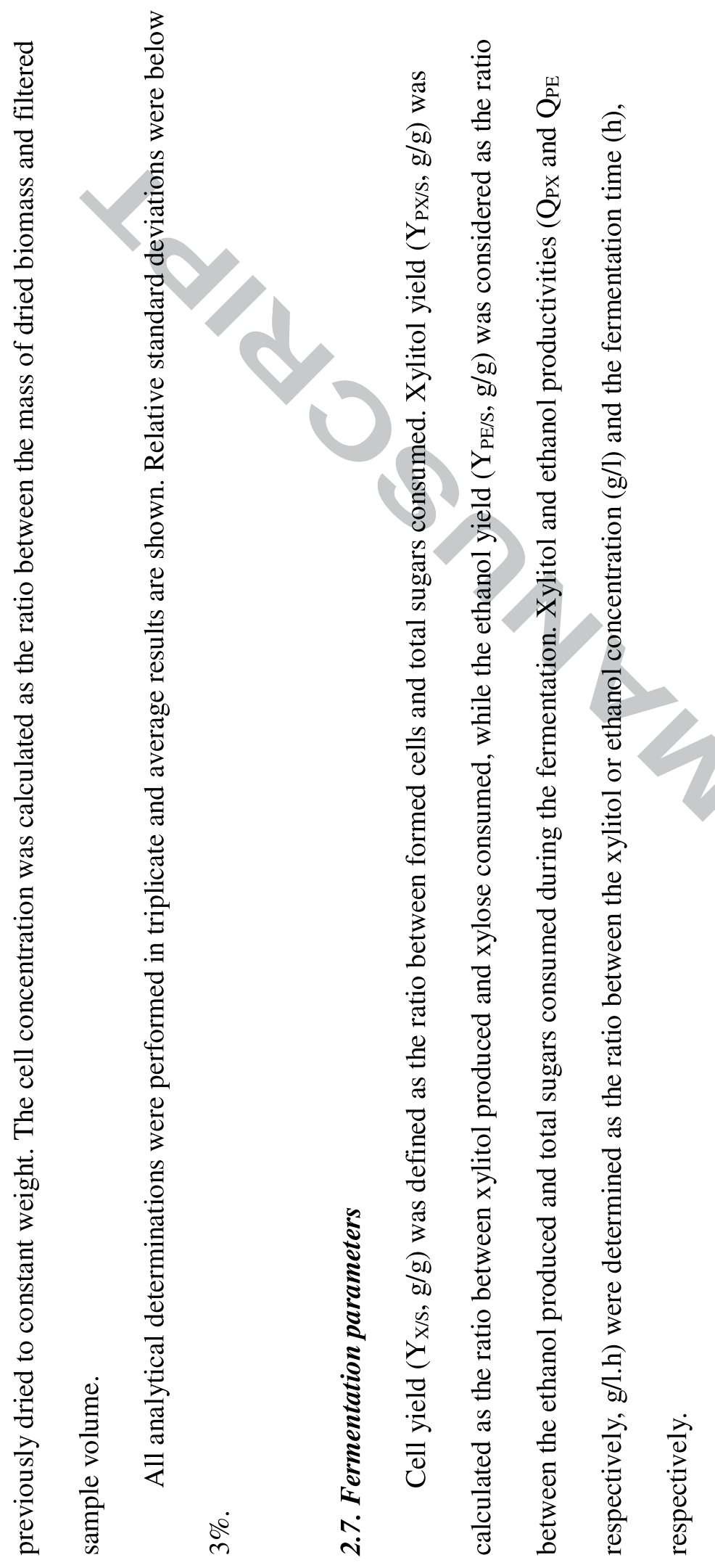

감 


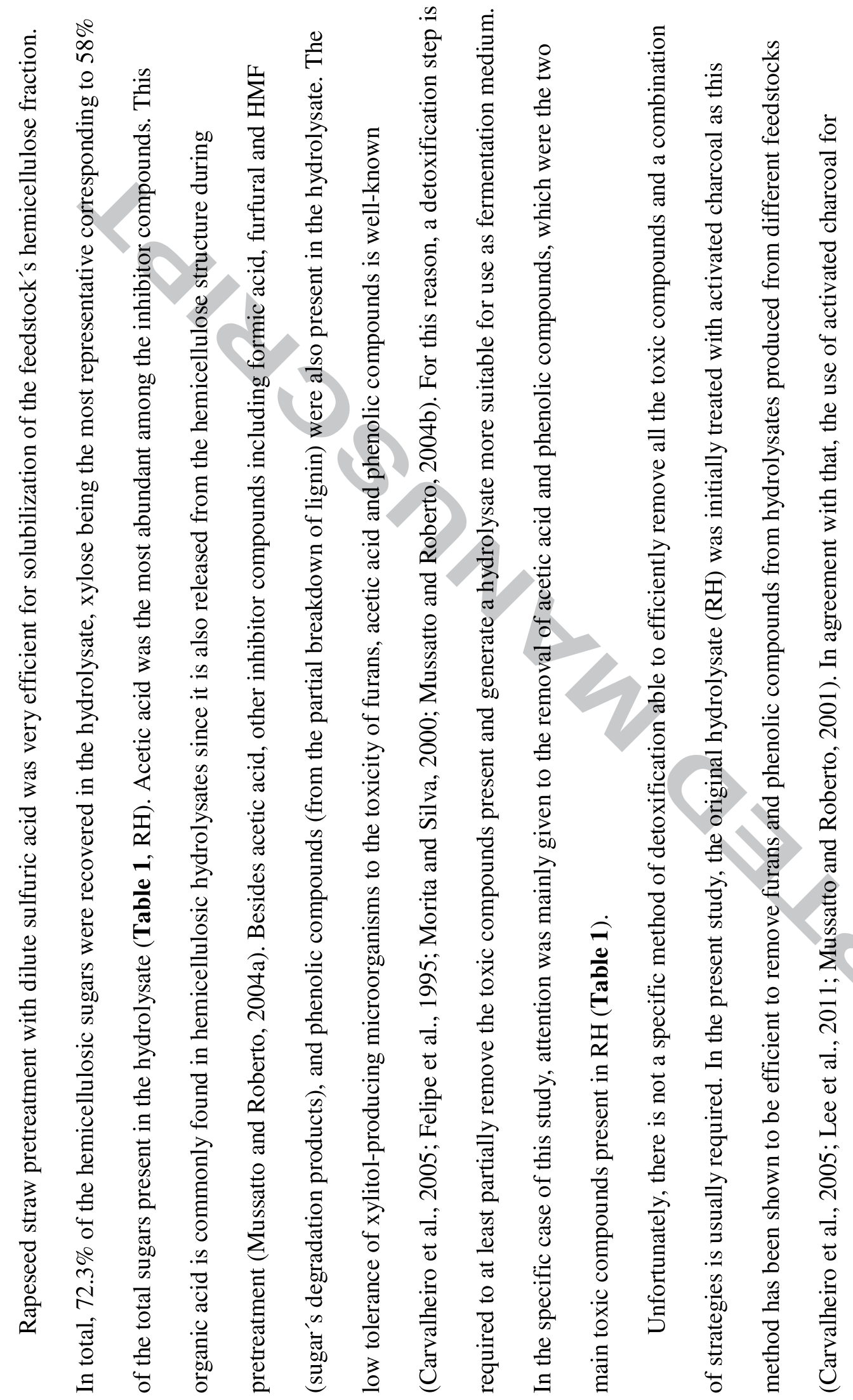




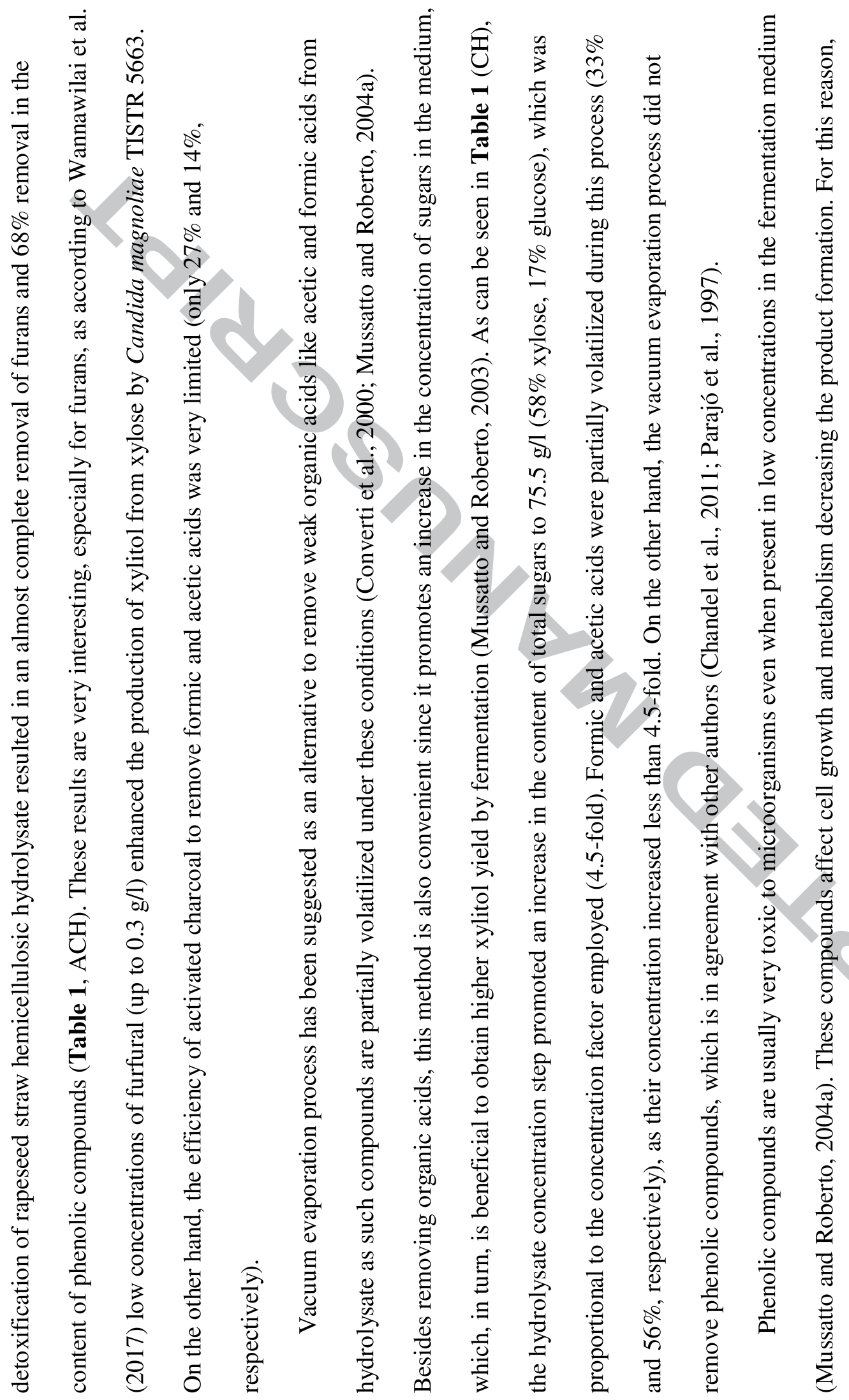




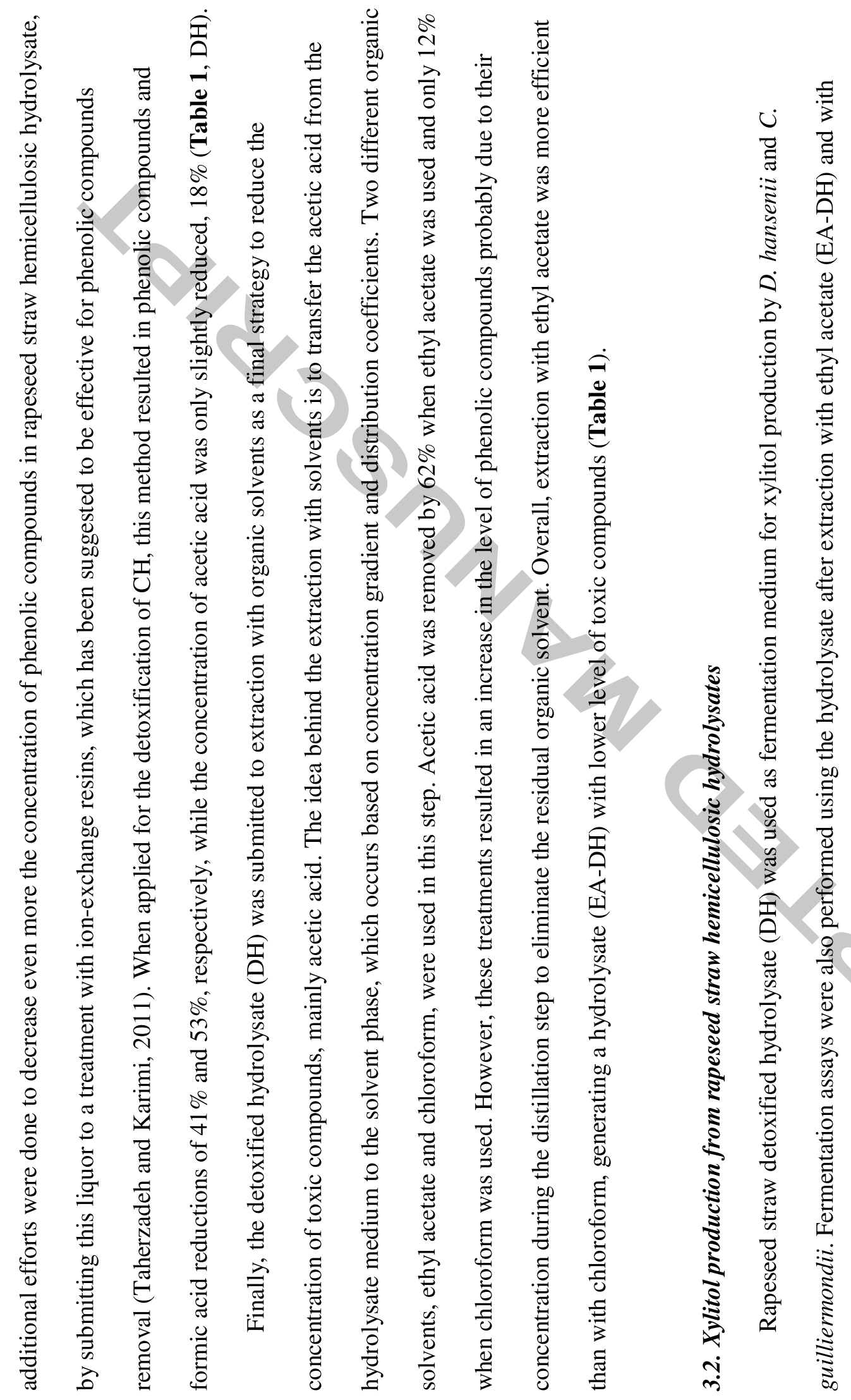




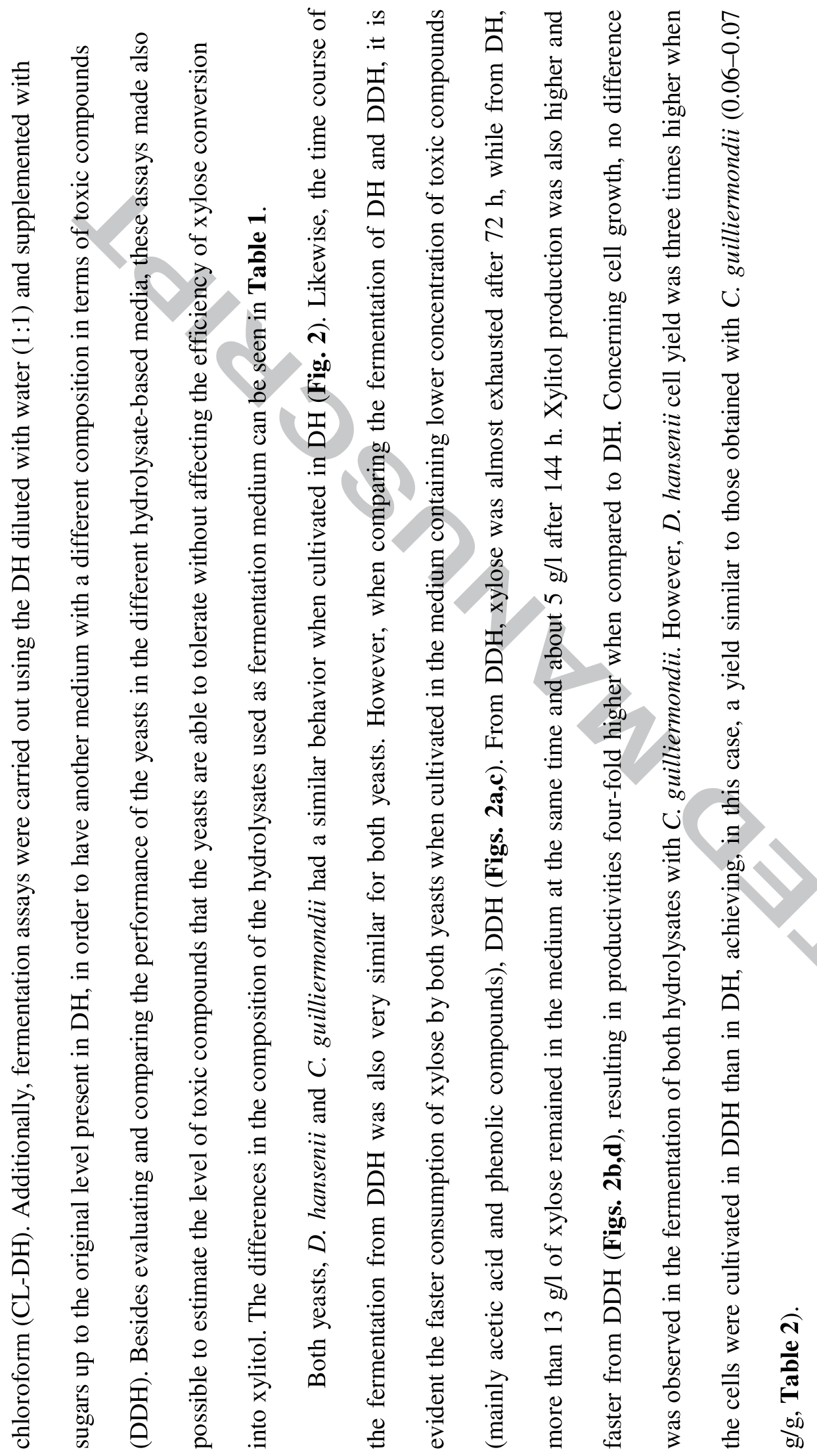




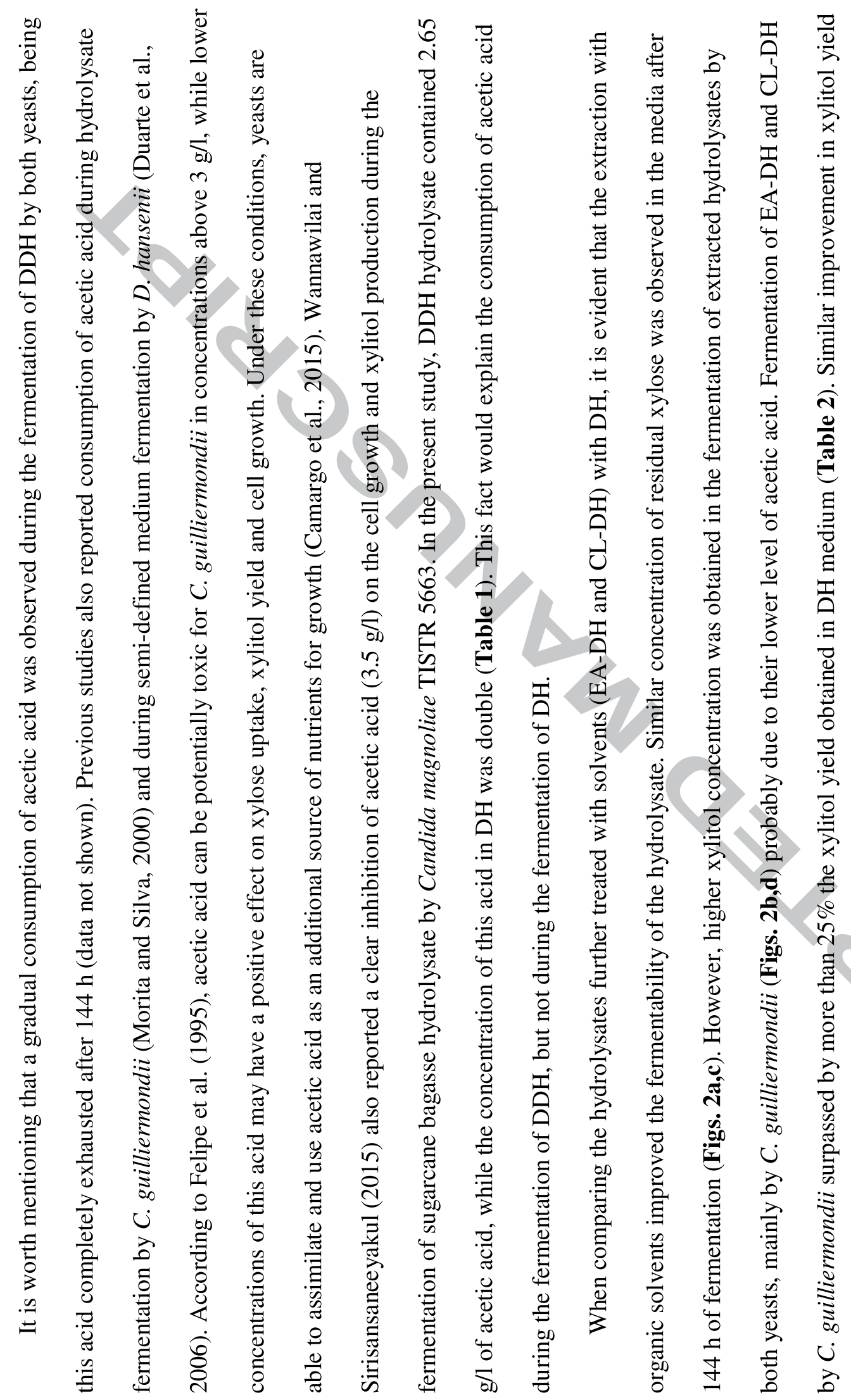




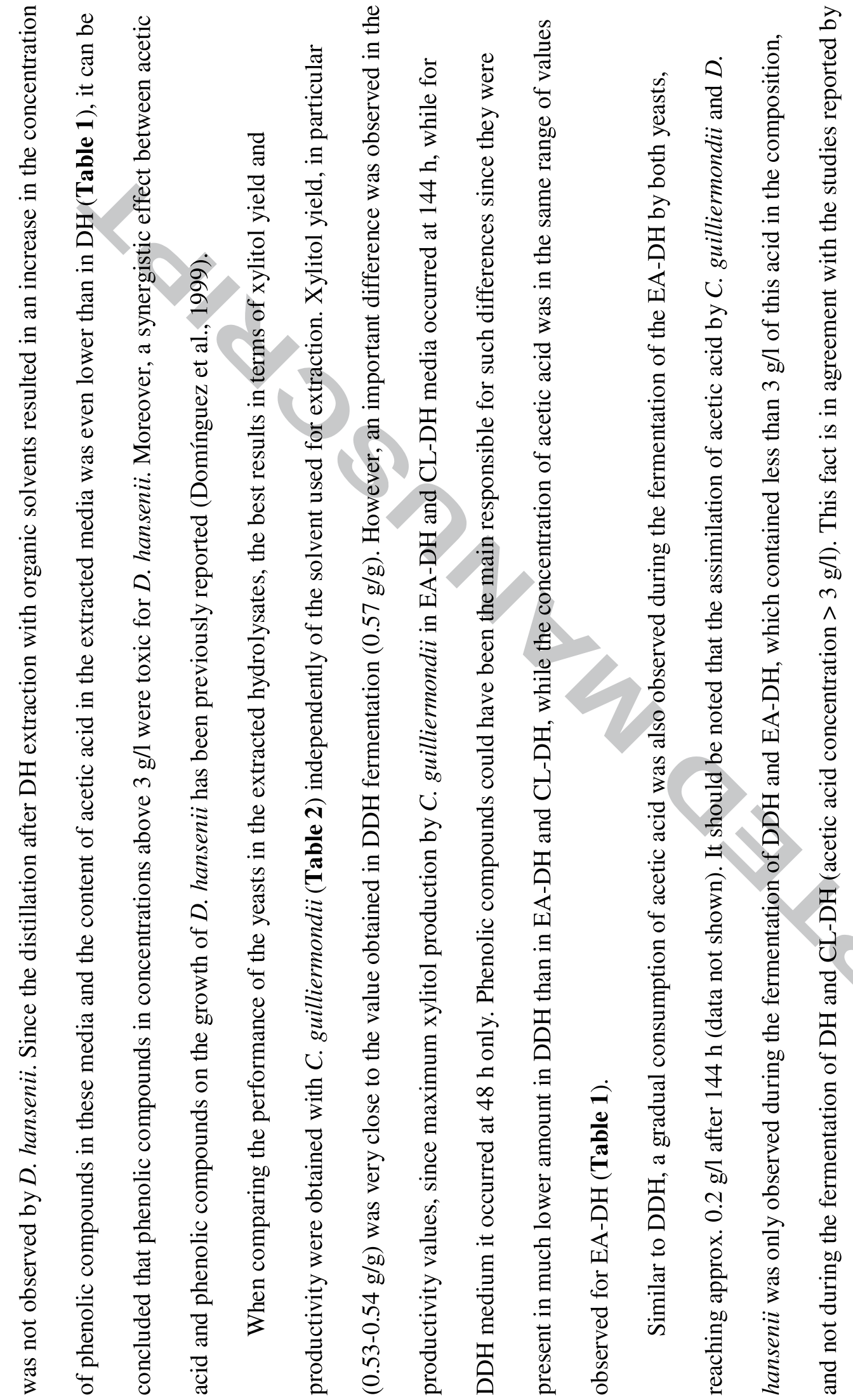




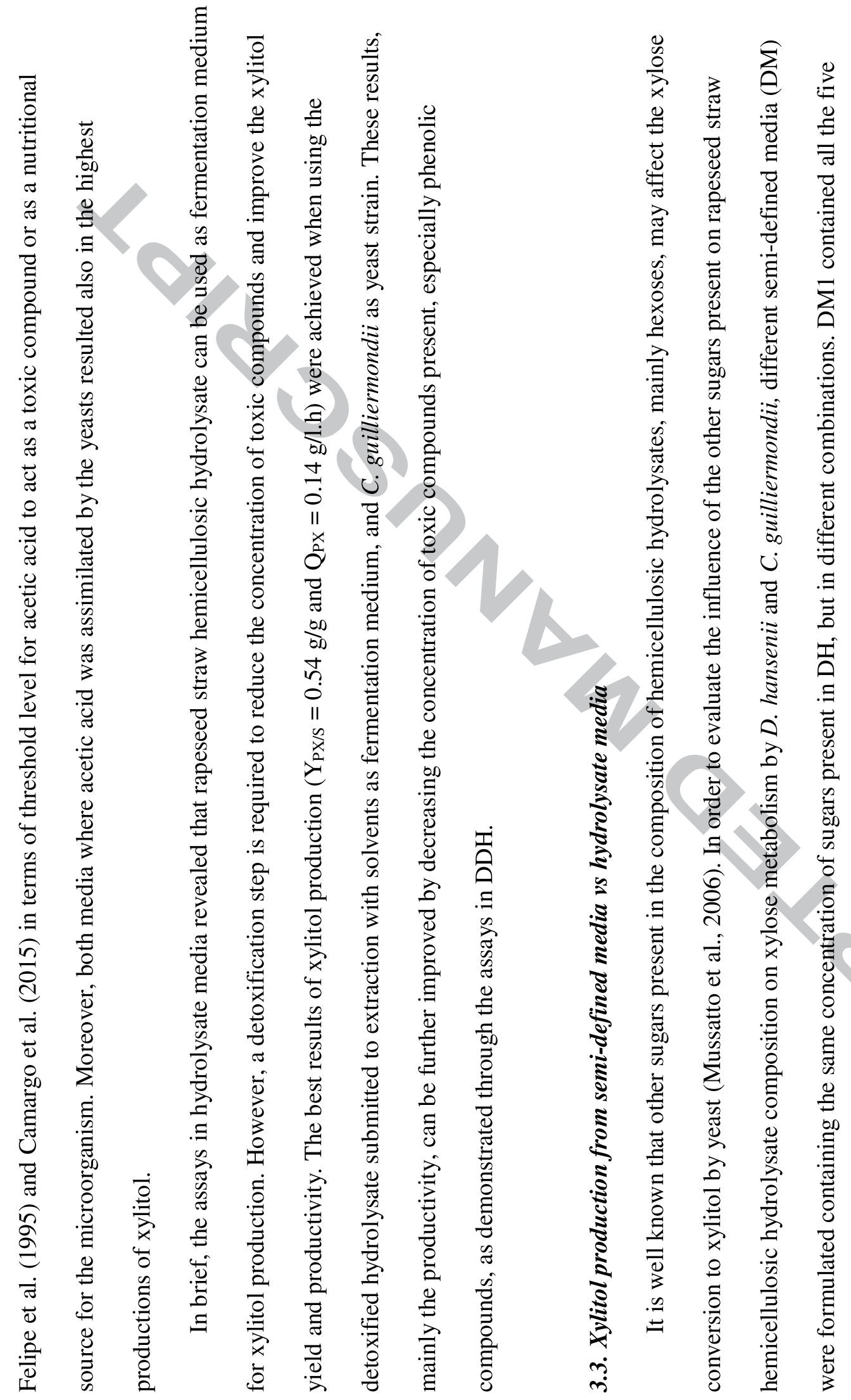




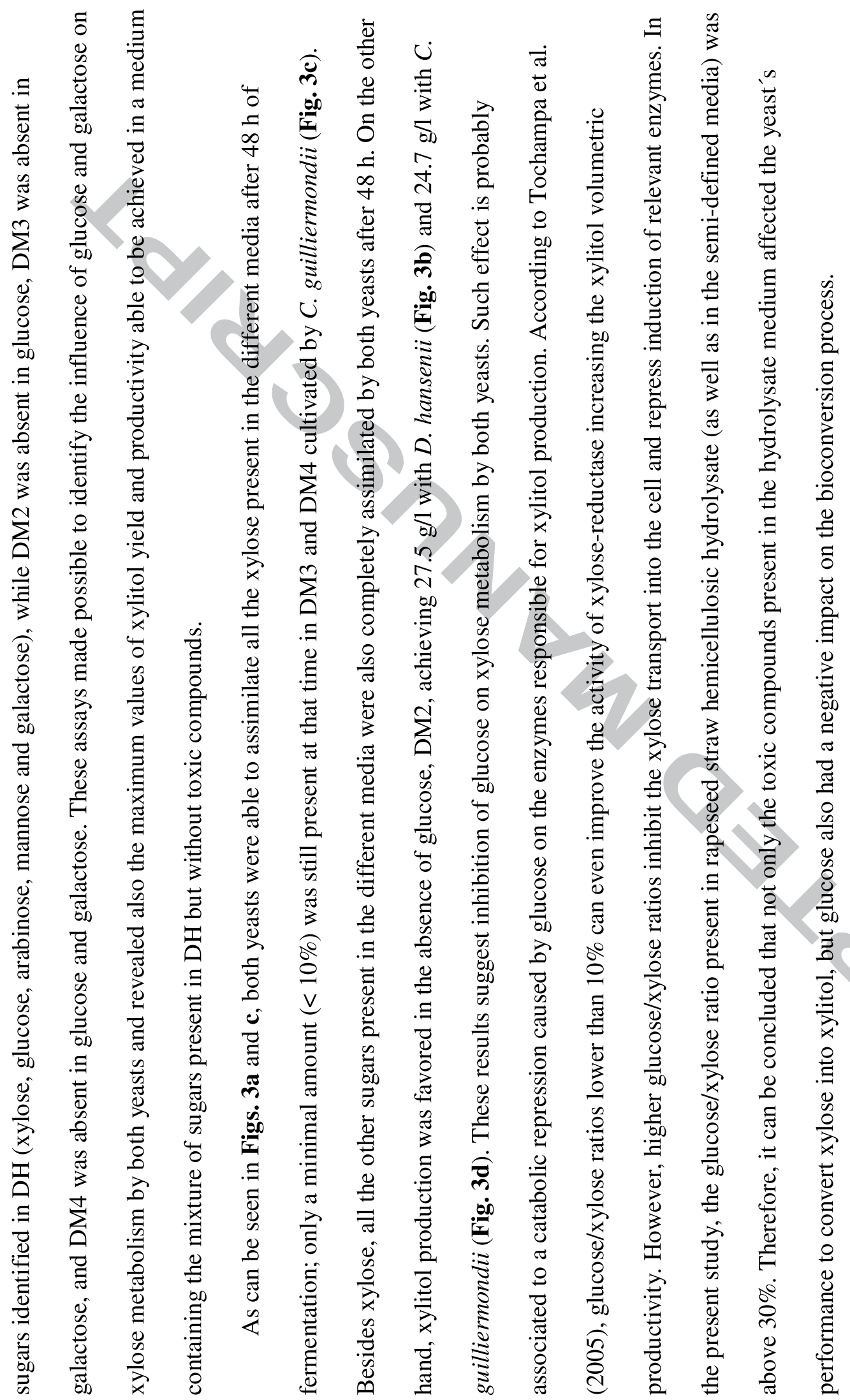




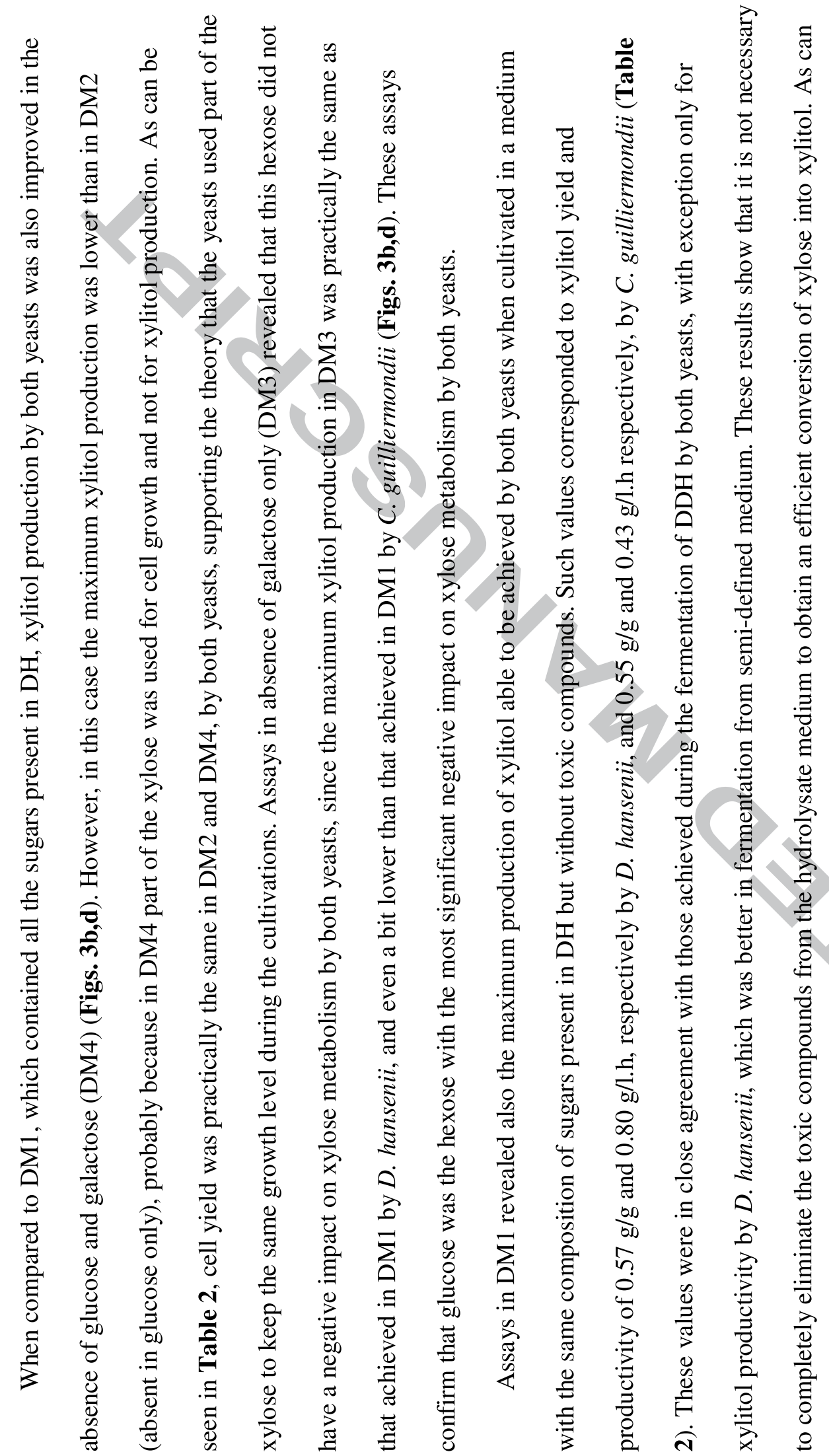




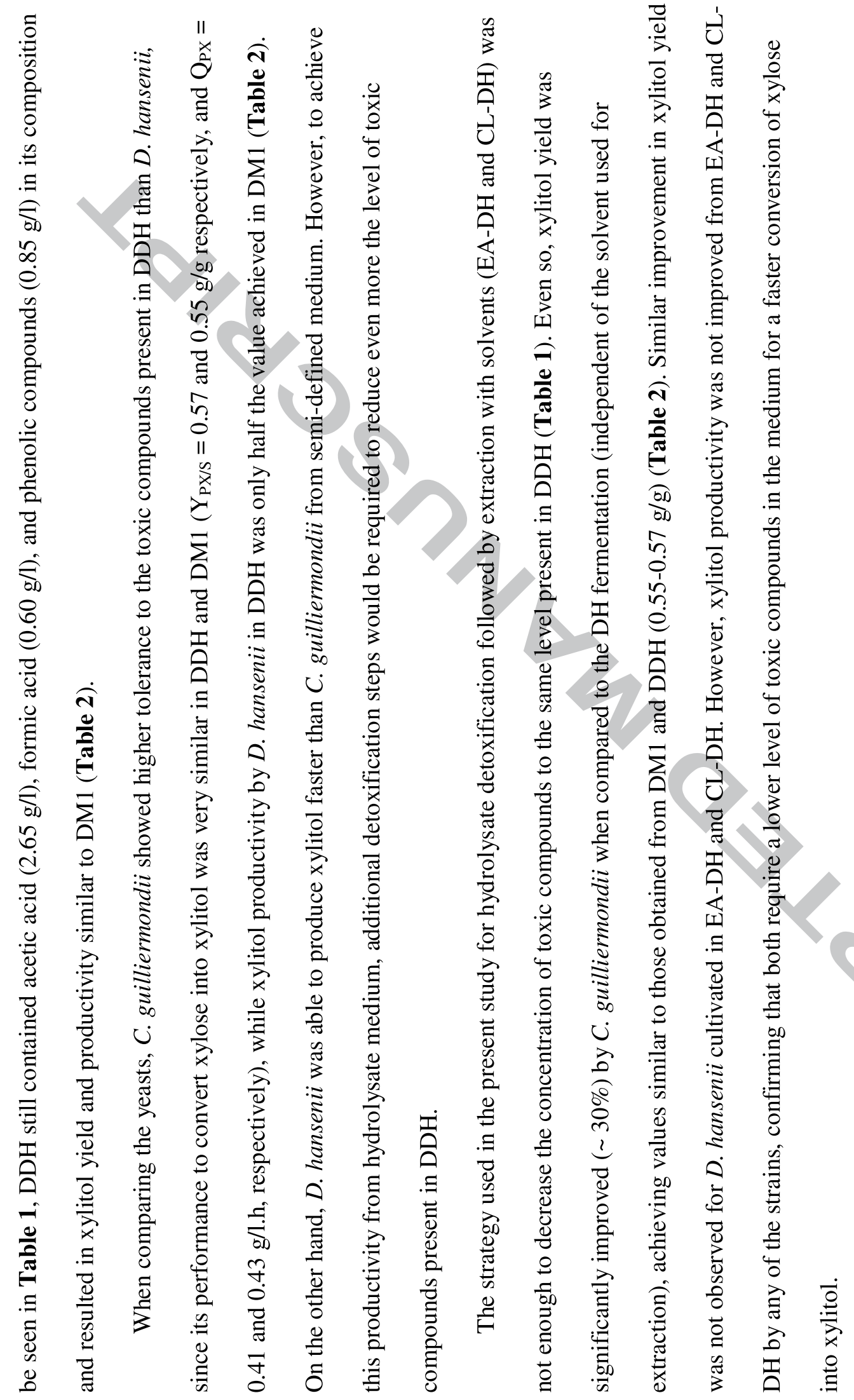




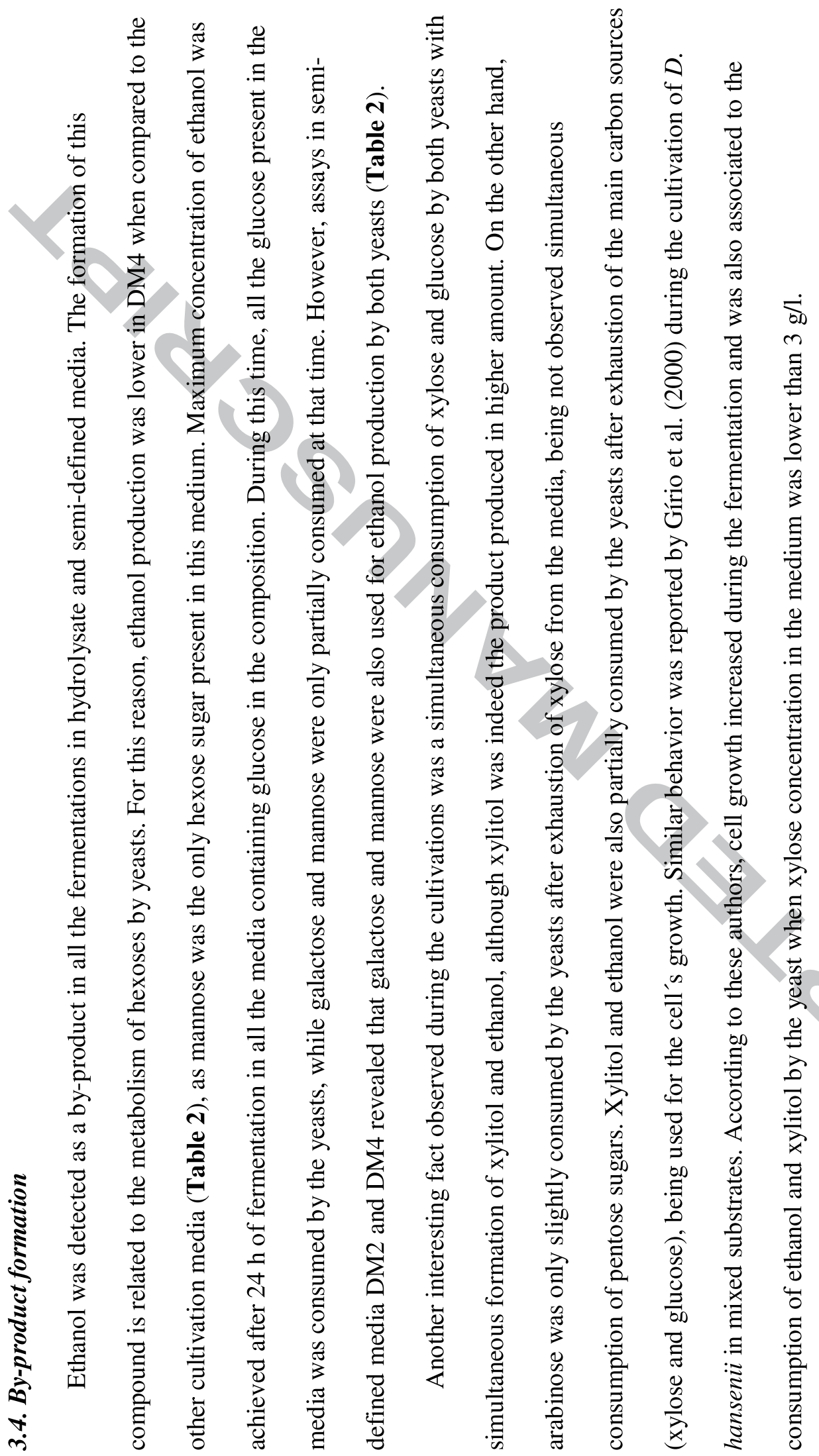

$\approx$ 


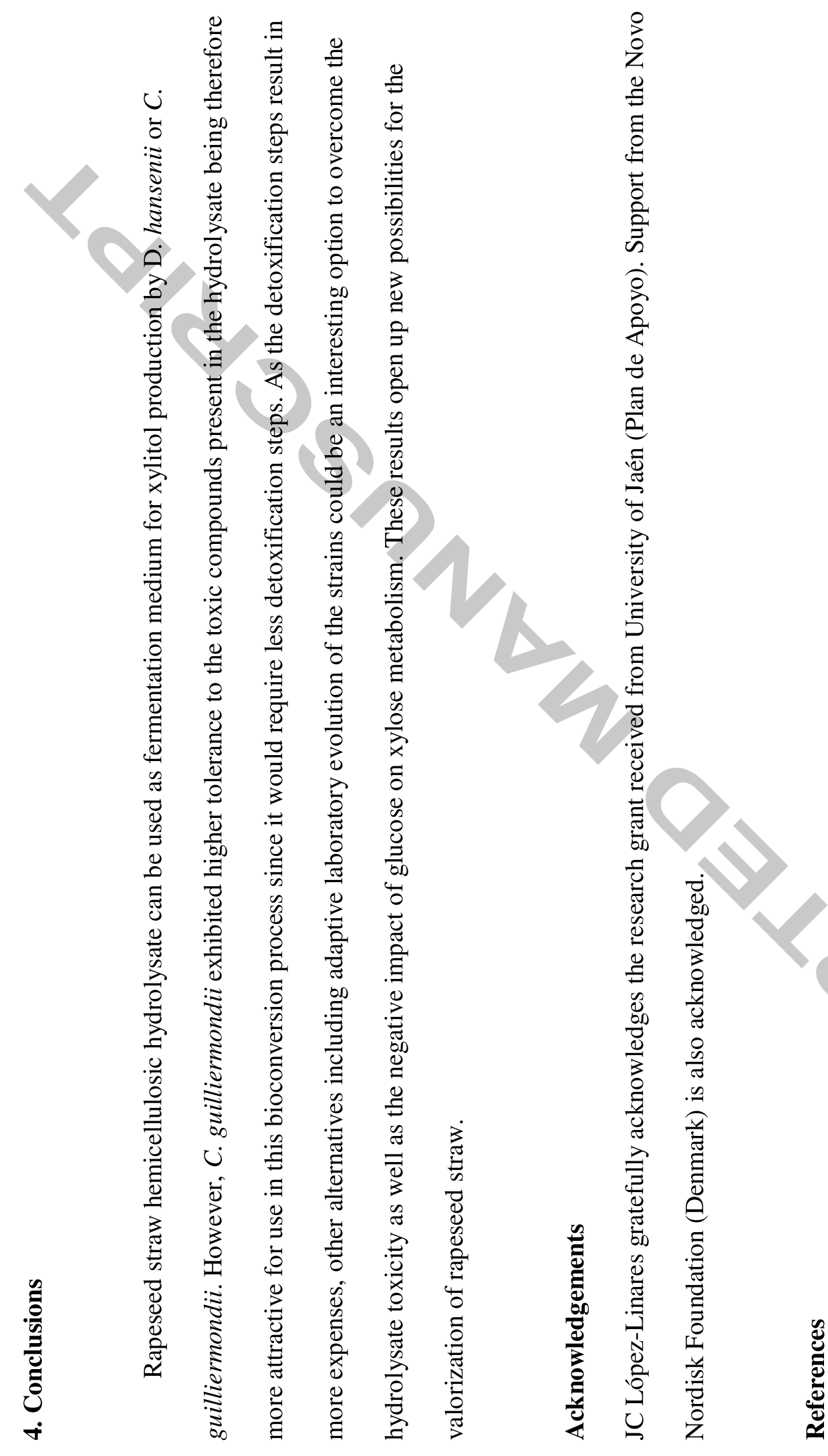

$\approx$ 


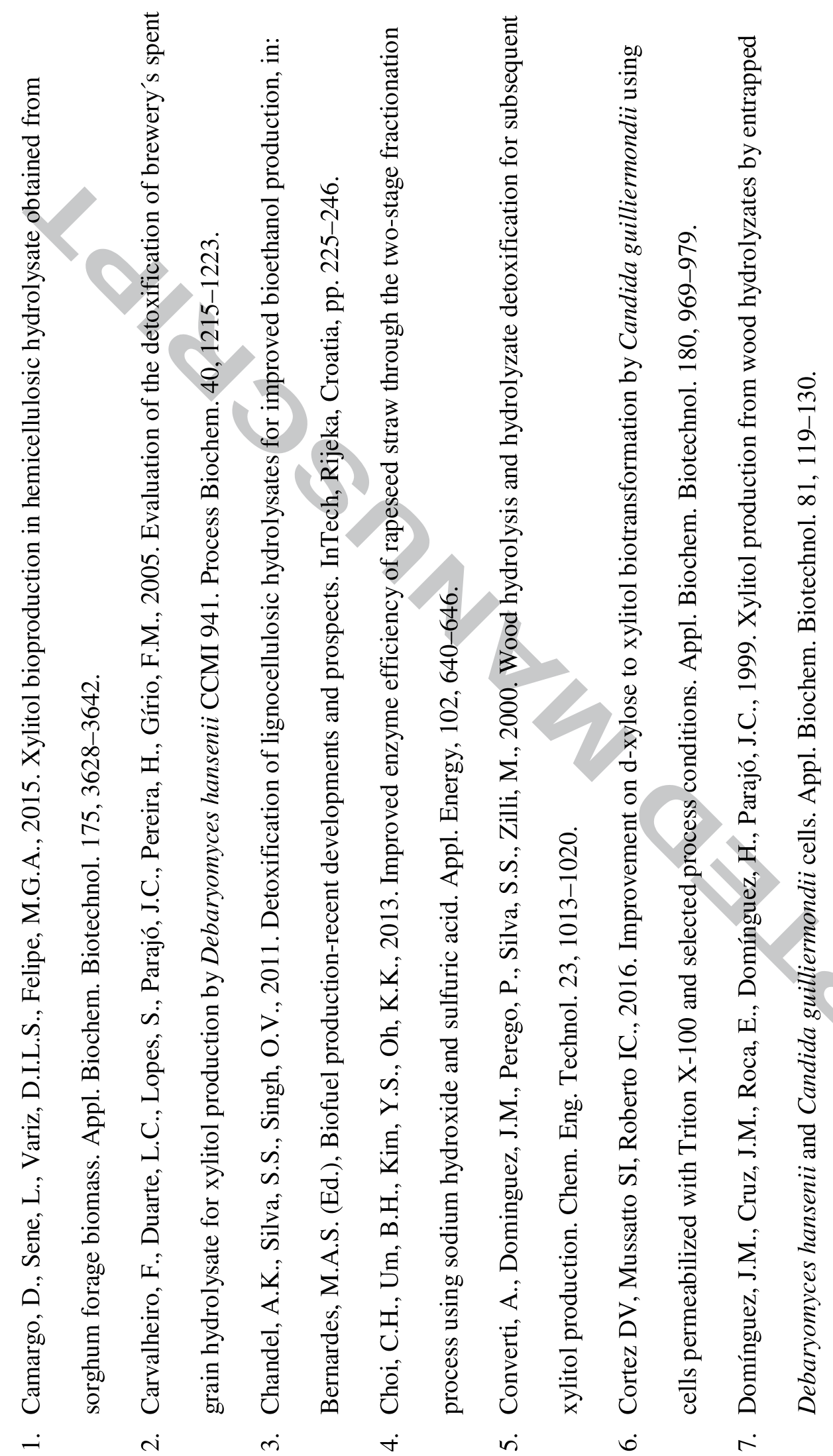




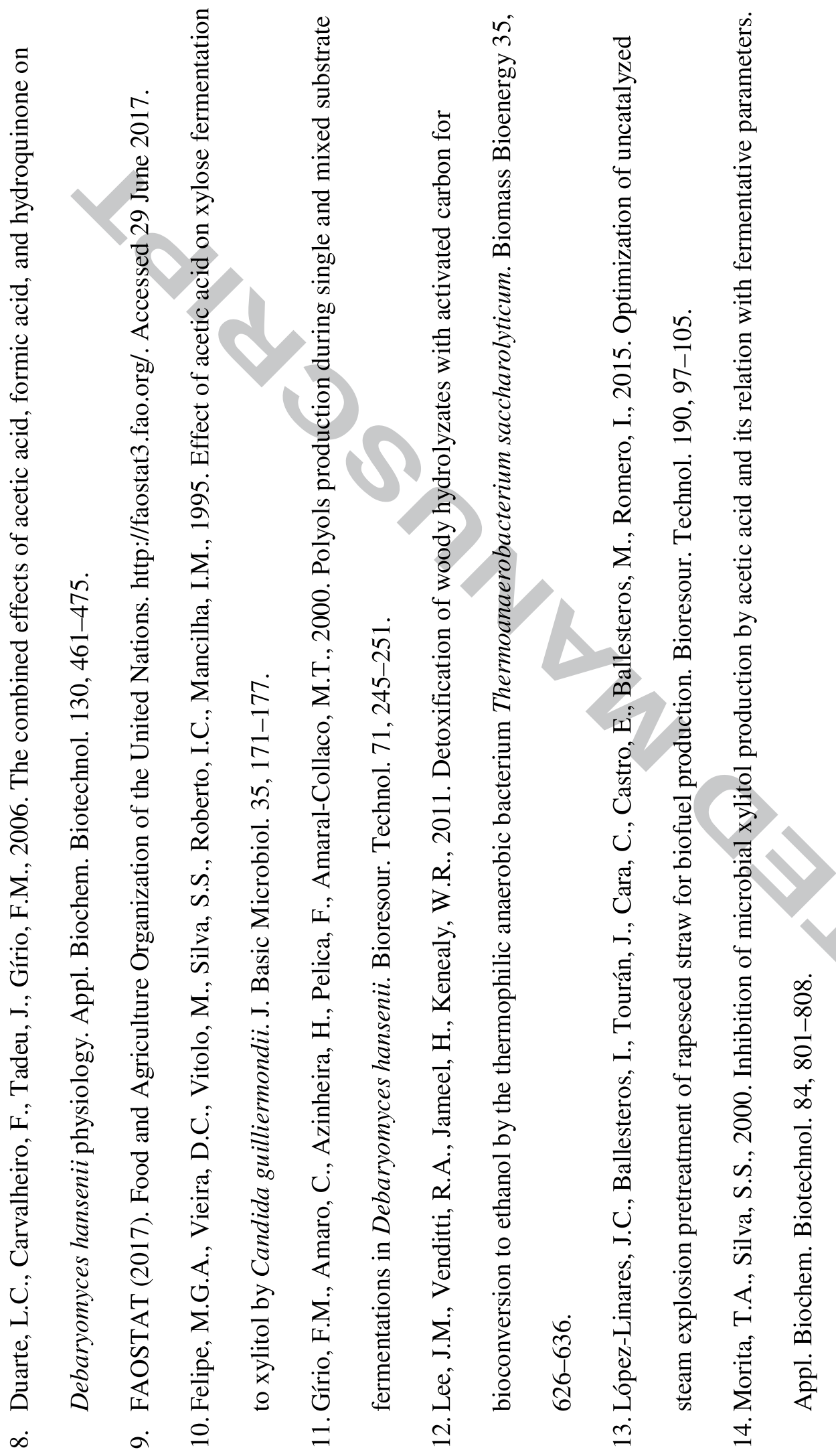




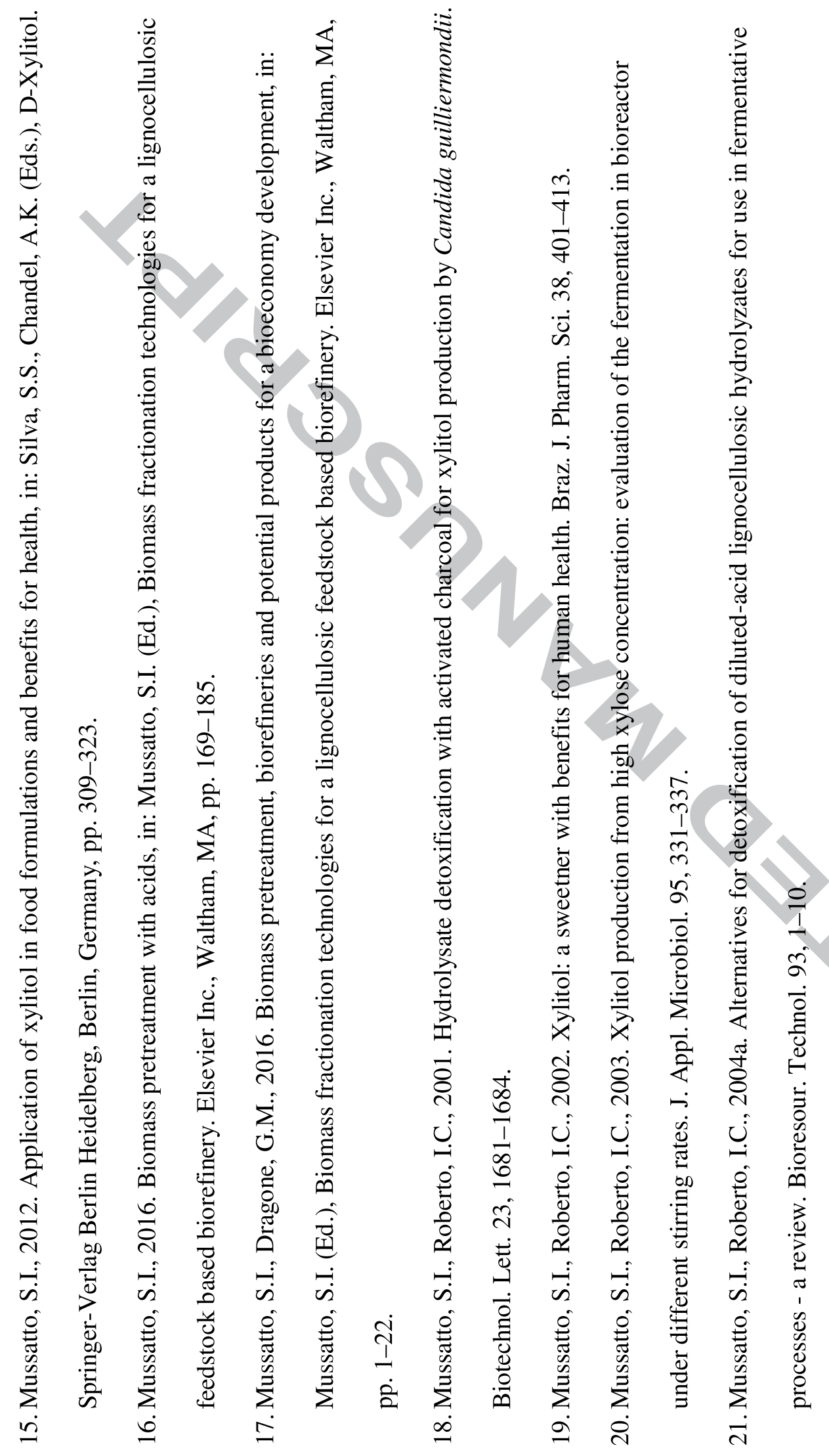

$\stackrel{\sim}{\sim}$ 


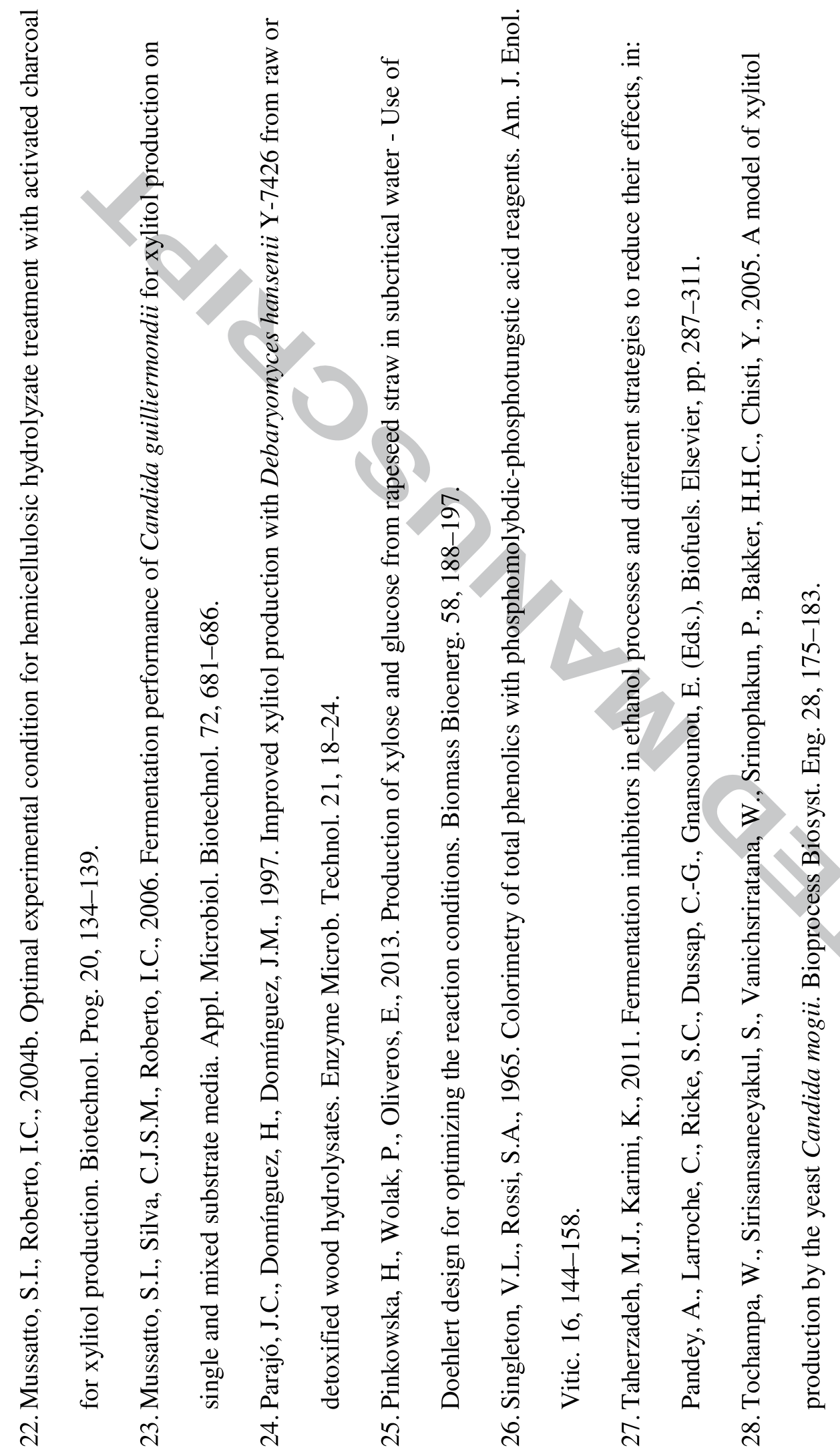

N 

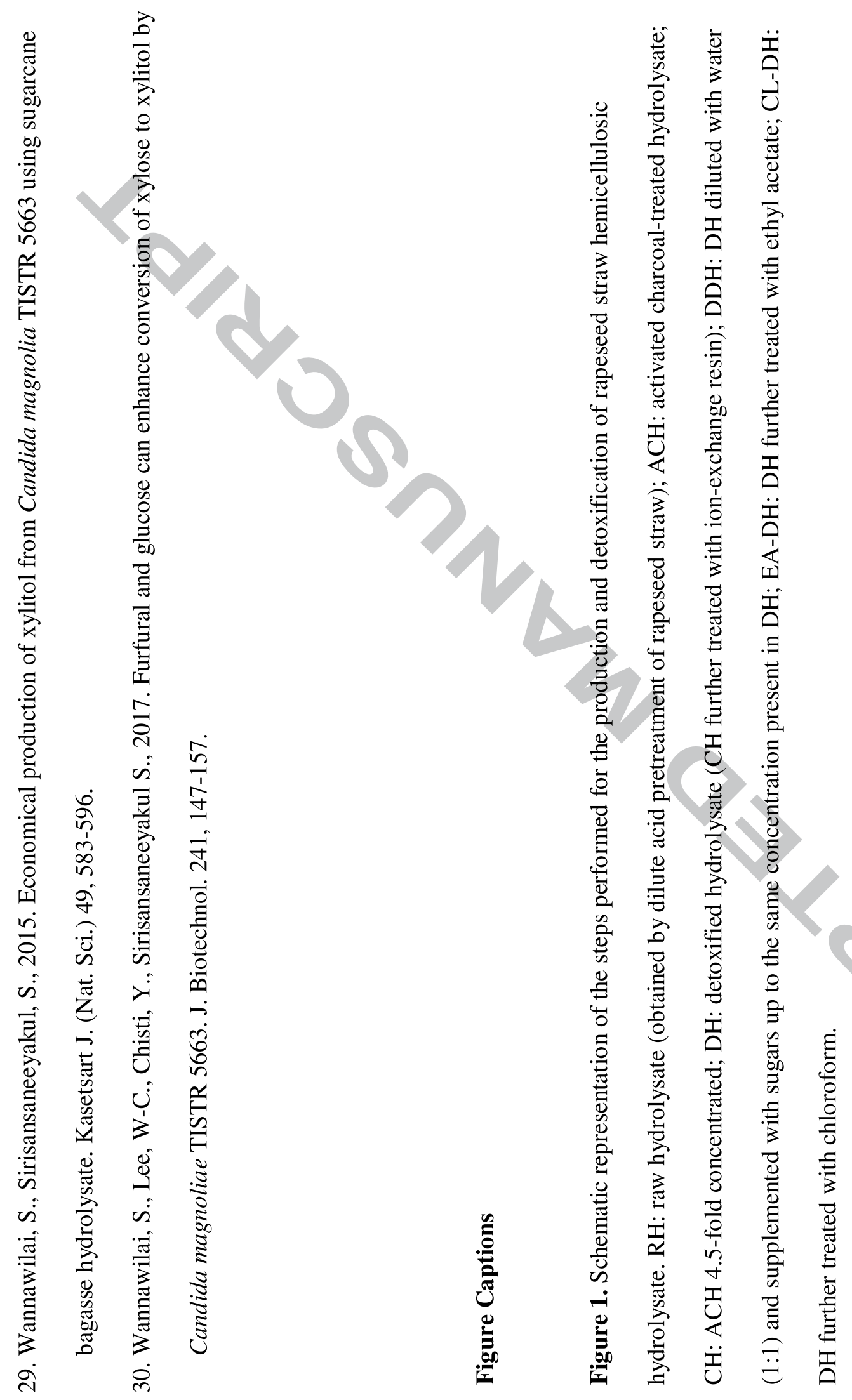


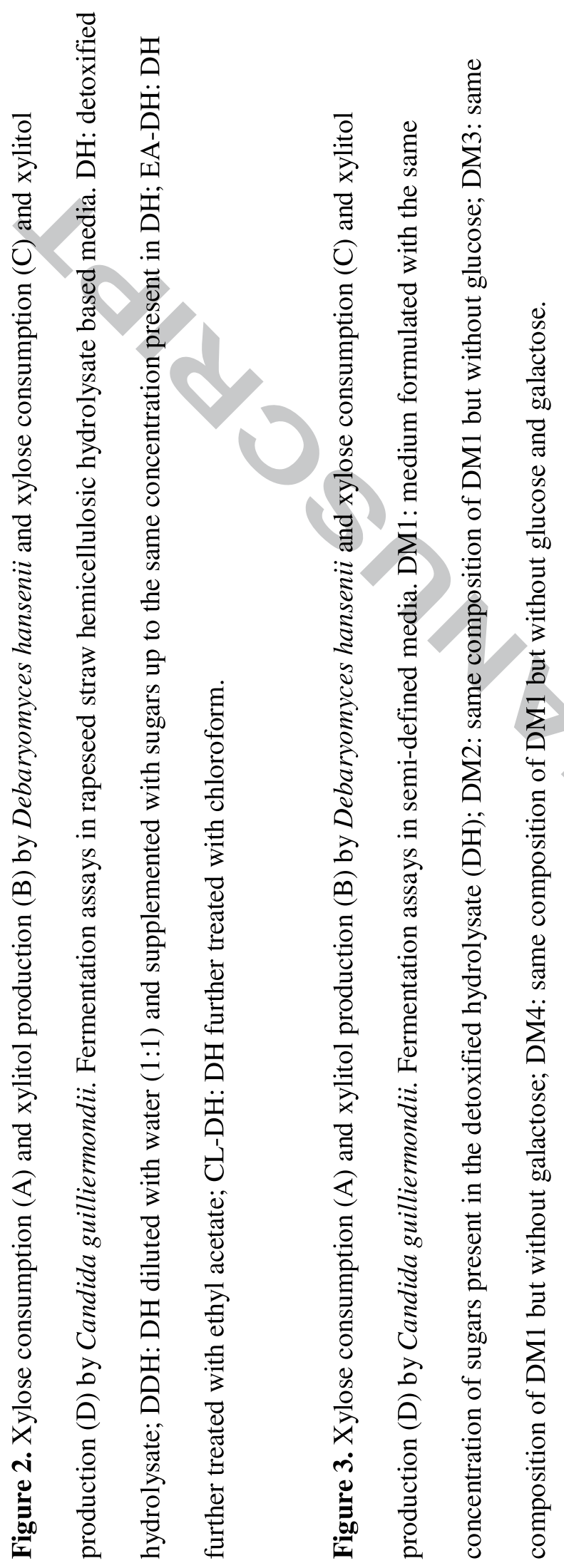




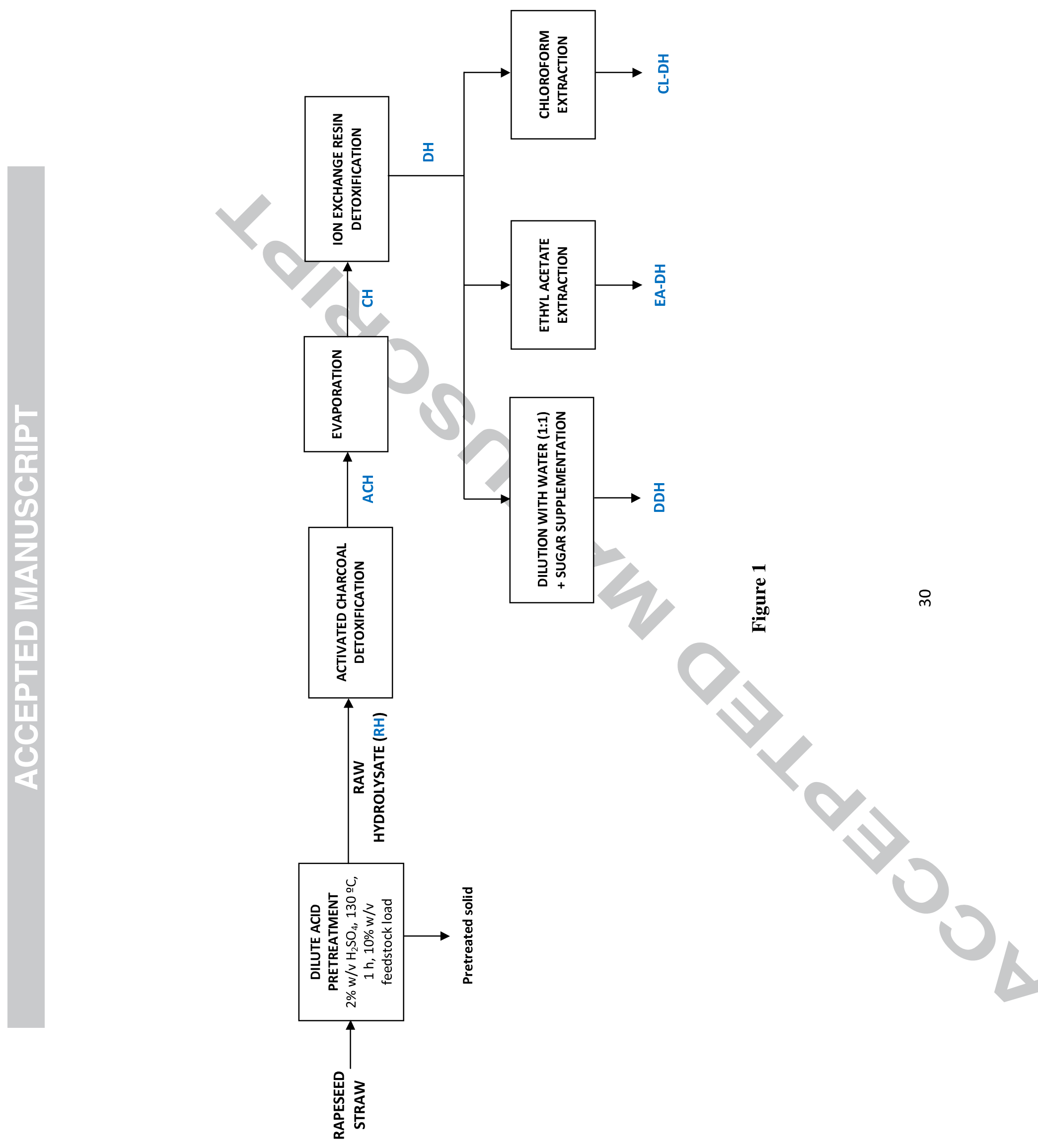



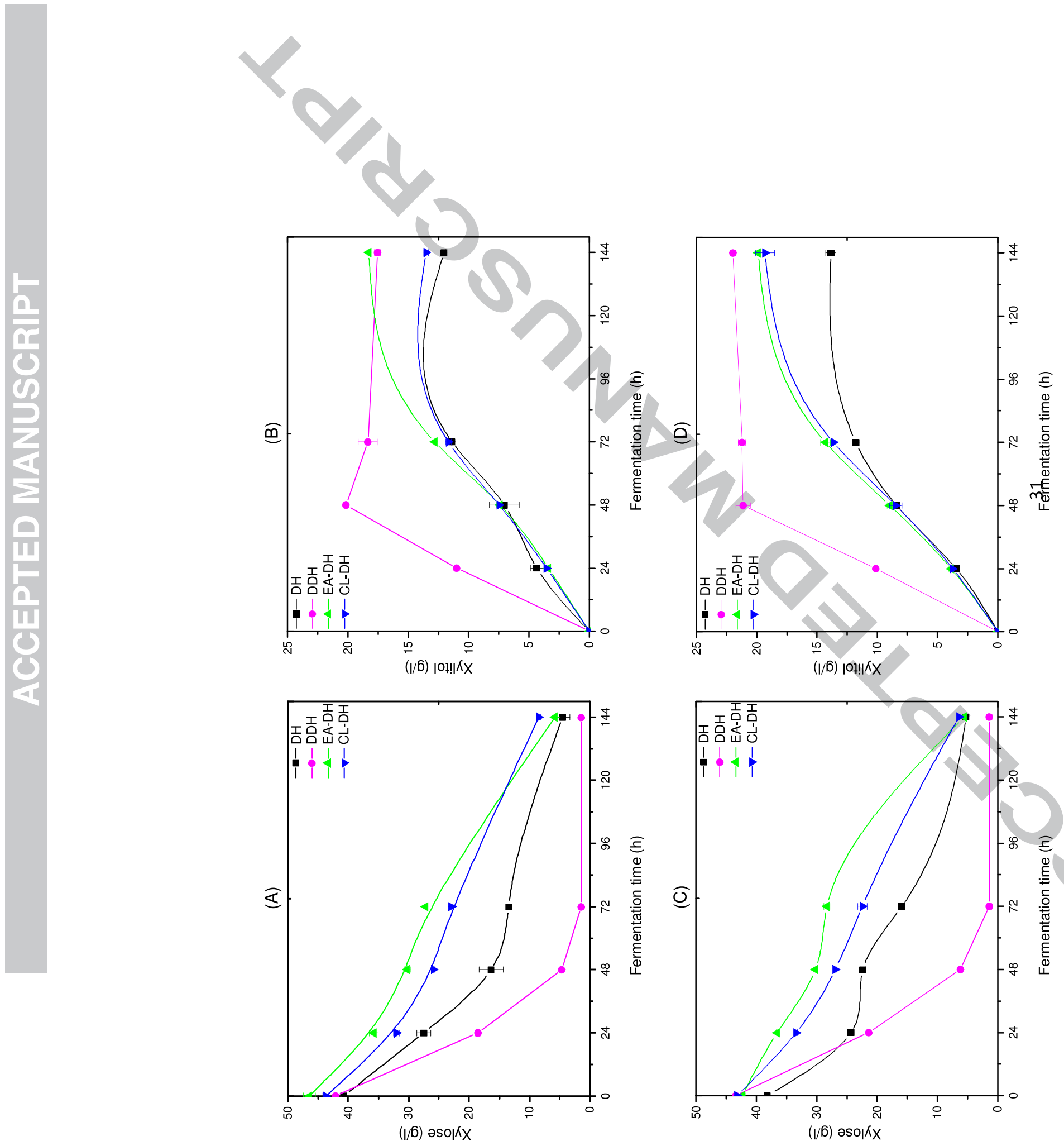

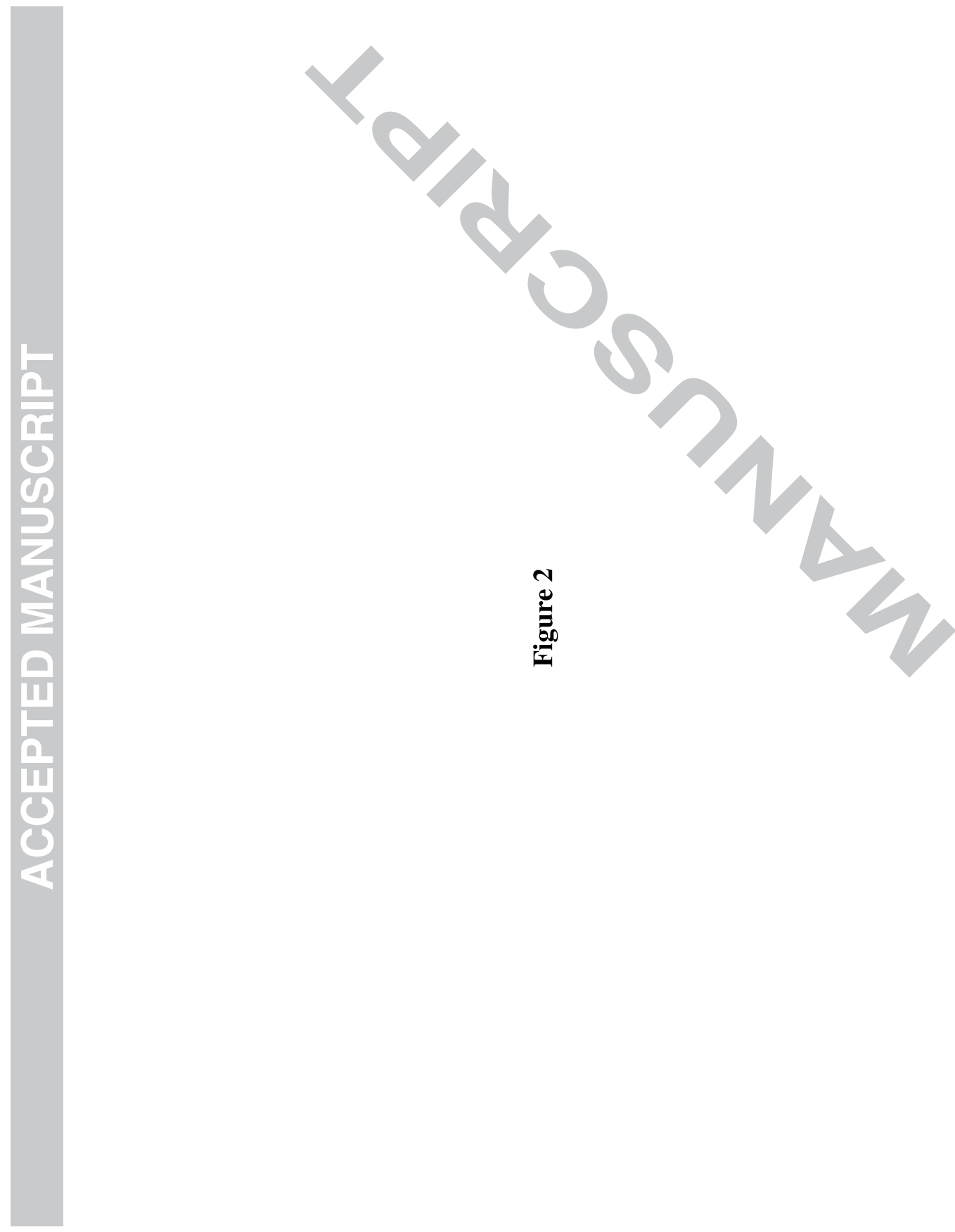

m

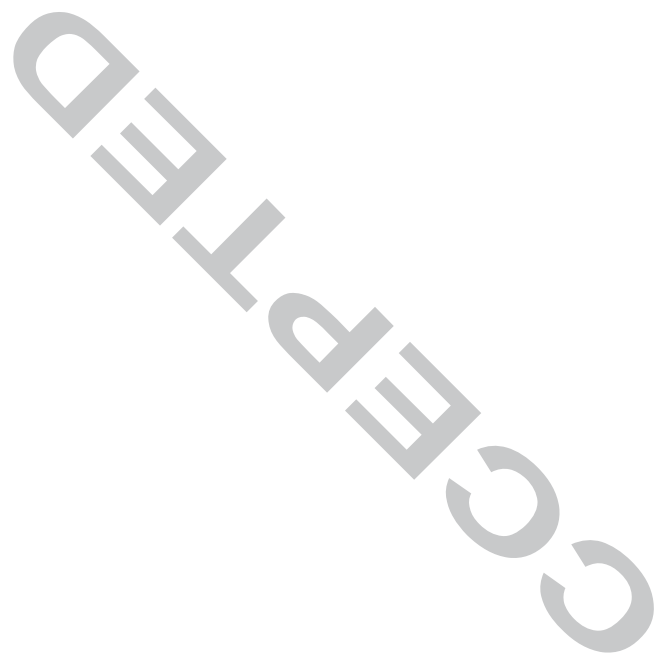



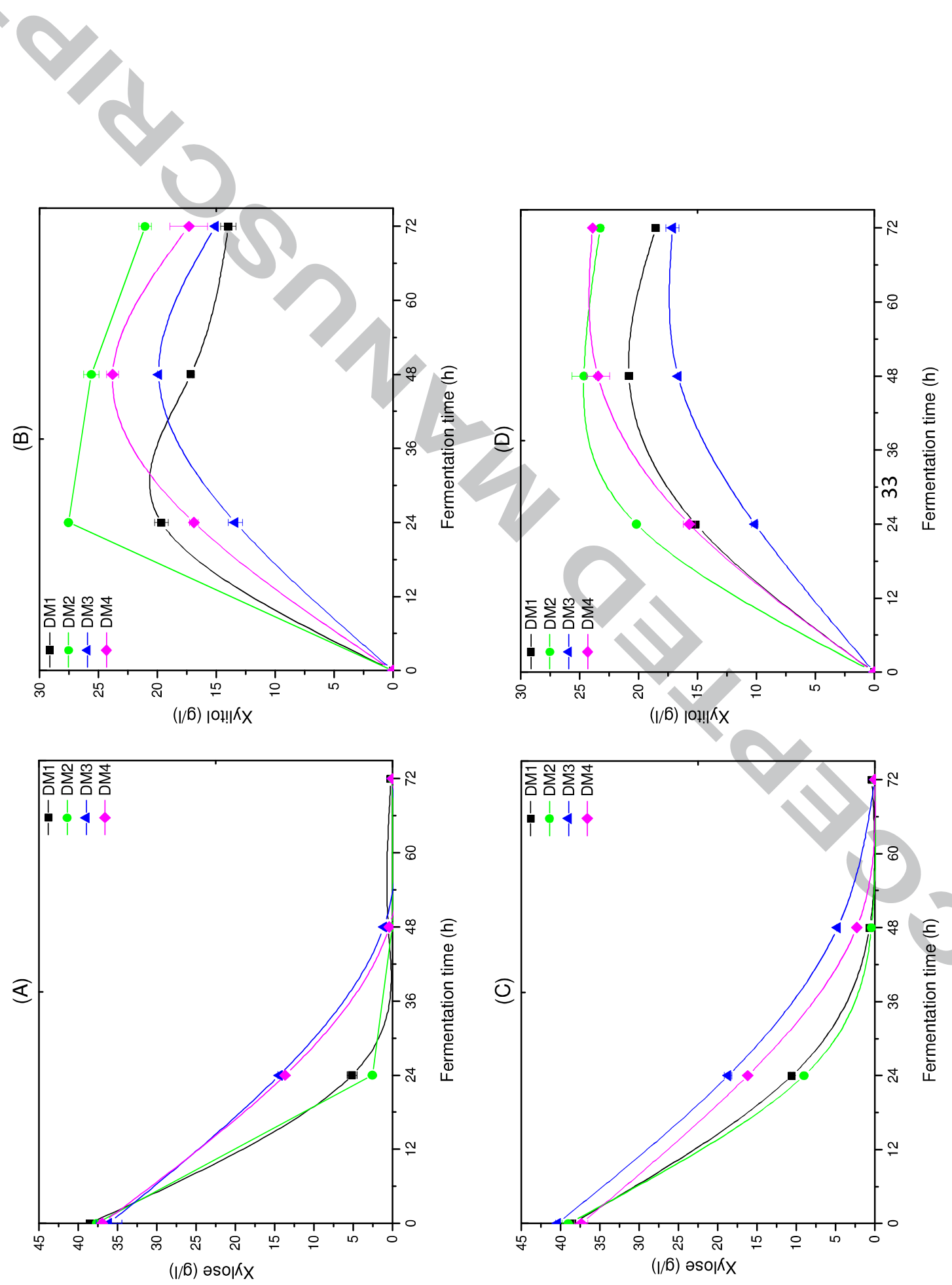

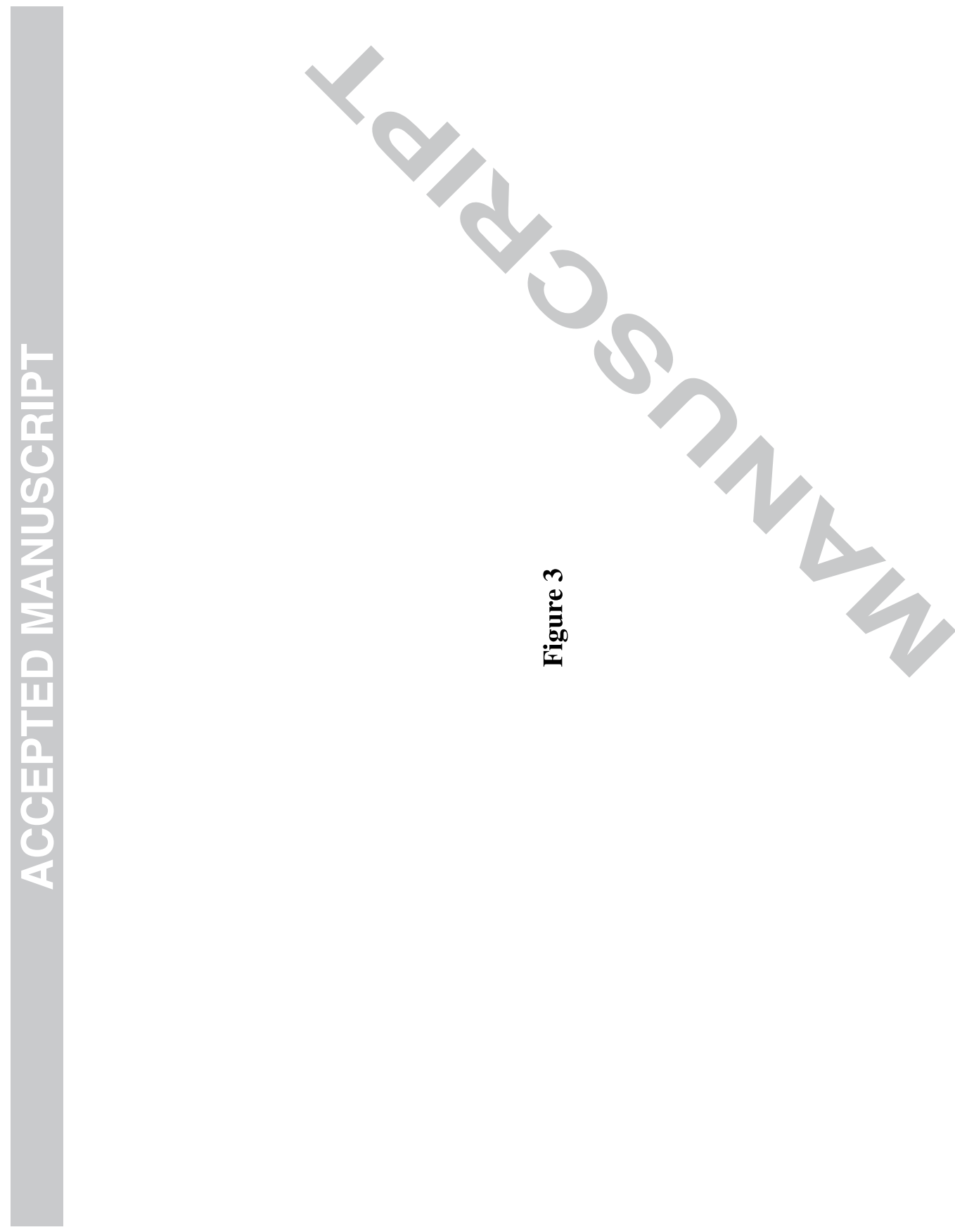

$\stackrel{+}{m}$

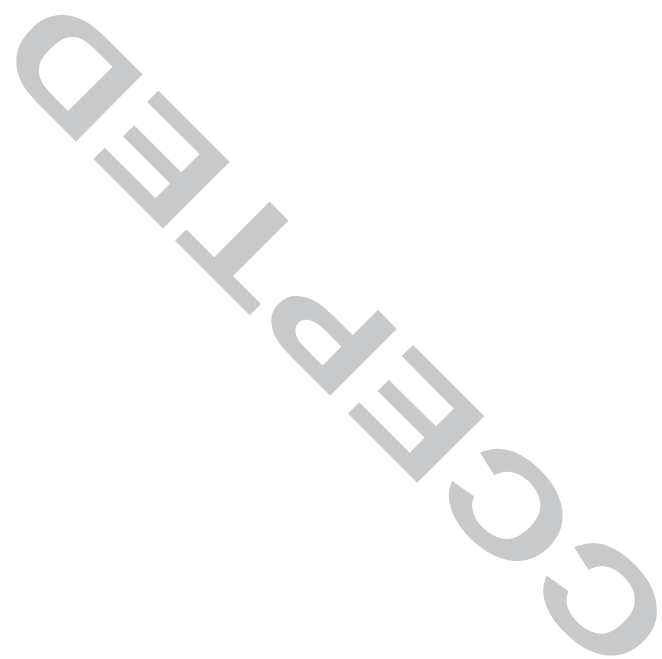




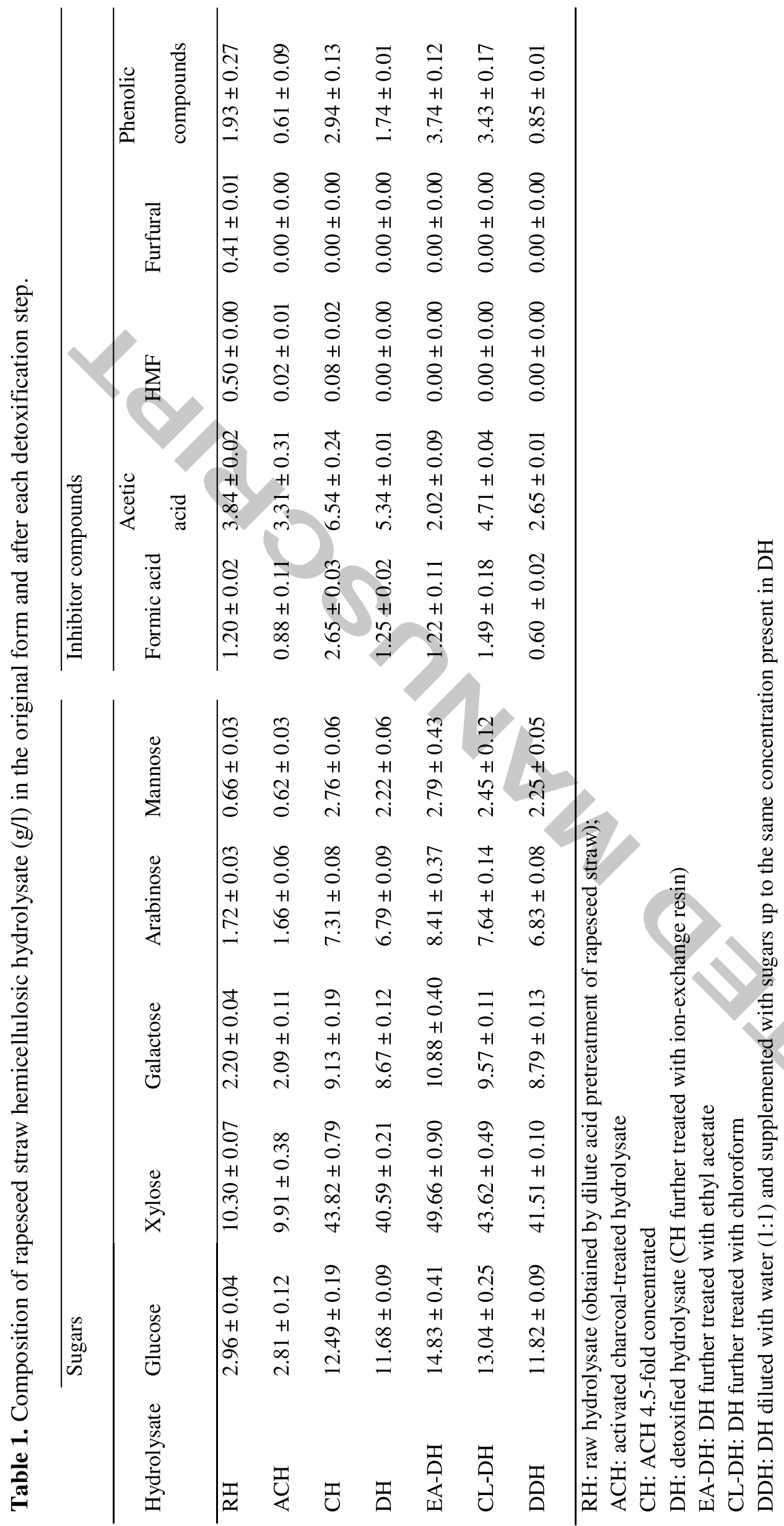




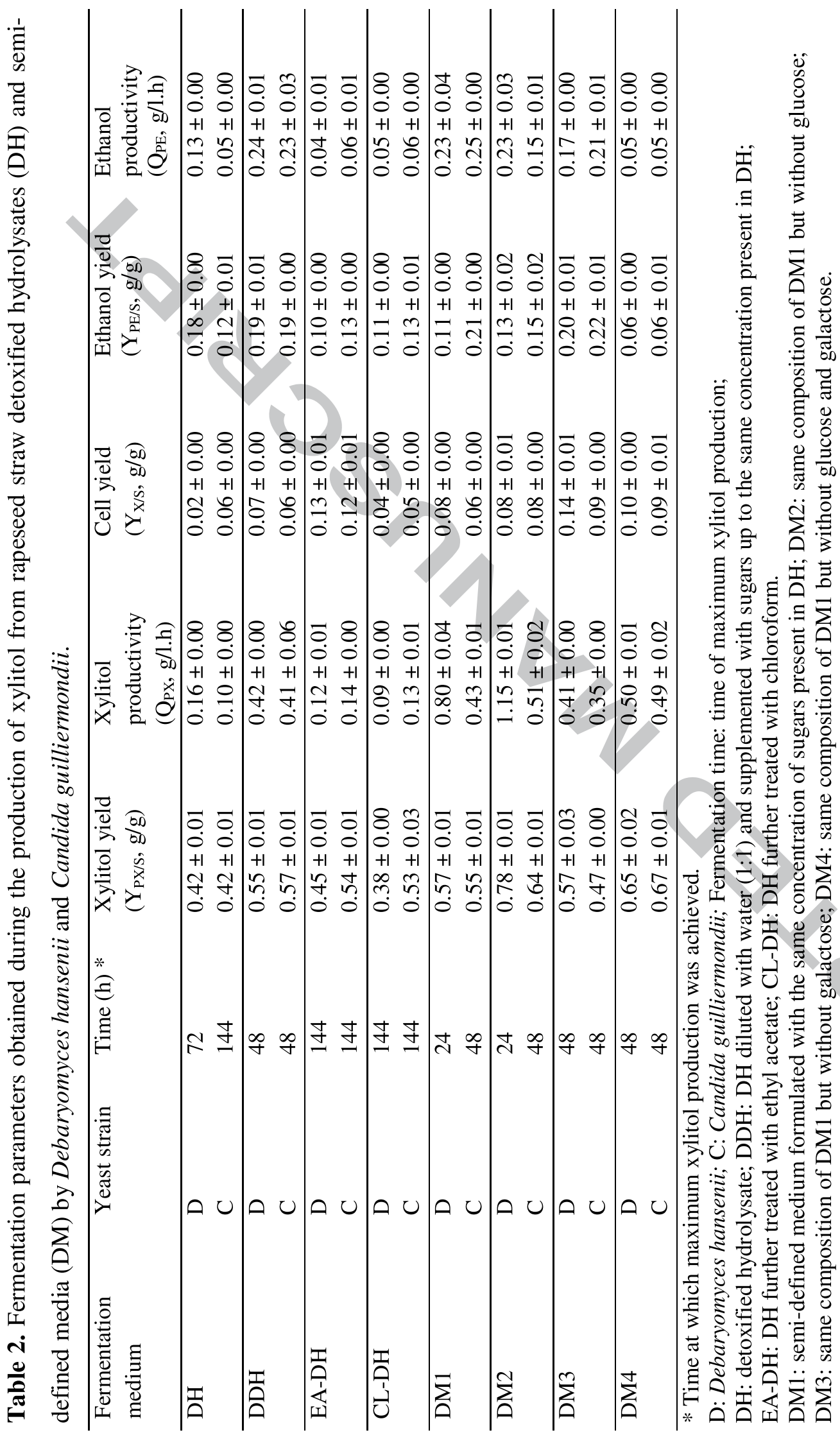

$m$ 


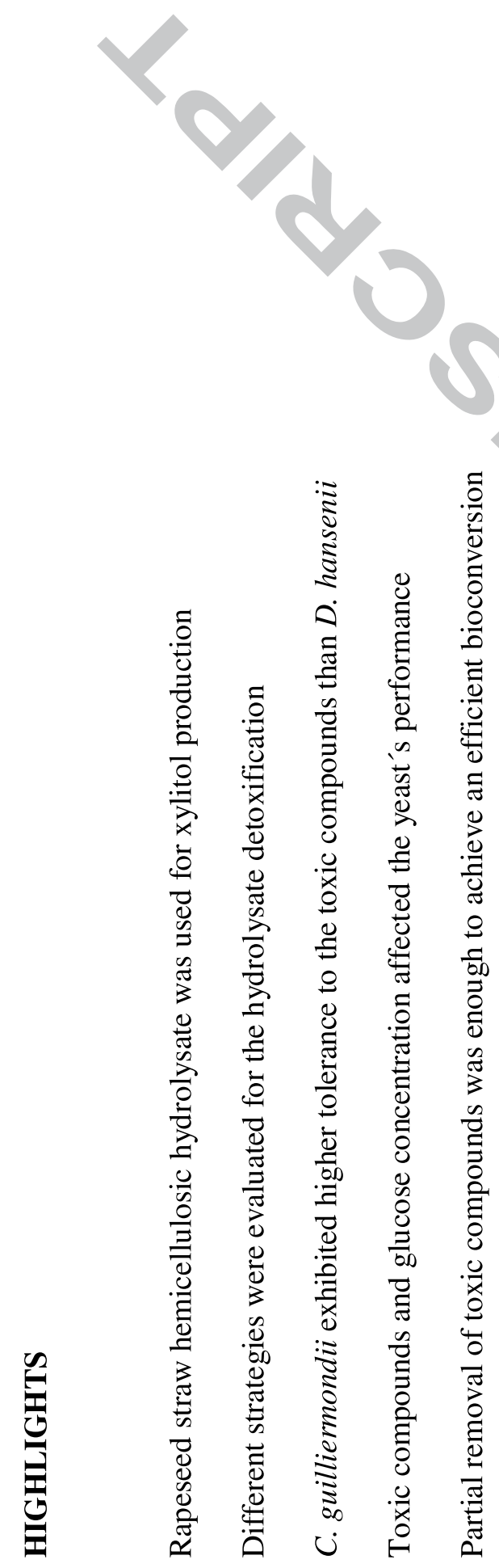

n 